\title{
The effect of J5 bacterins on clinical, behavioral, and antibody response following an Escherichia coli intramammary challenge in dairy cows at peak lactation
}

\author{
N. M. Steele, ${ }^{1,2 *}$ ๑ T. H. Swartz, ${ }^{1} \odot$ K. M. Enger, ${ }^{3}$ H. Schramm, ${ }^{4}$ R. R. Cockrum, ${ }^{1} \odot$ S. J. Lacy-Hulbert, ${ }^{2} \oplus$ \\ R. R. White, ${ }^{5}$ J. Hogan, ${ }^{3}{ }^{\circledR}$ and C. S. Petersson-Wolfe ${ }^{1}{ }^{\circledR}$ \\ ${ }^{1}$ Department of Dairy Science, Virginia Tech, Blacksburg 24061 \\ ${ }^{2}$ DairyNZ Ltd., Private Bag 3221, Hamilton 3240, New Zealand \\ ${ }^{3}$ Department of Animal Sciences, The Ohio State University, Wooster 44691 \\ ${ }^{4}$ Virginia-Maryland Regional College of Veterinary Medicine, Blacksburg 24061 \\ ${ }^{5}$ Department of Animal and Poultry Science, Virginia Tech, Blacksburg 24061
}

\section{ABSTRACT}

Vaccination against coliform mastitis has become part of mastitis control programs in the past 3 decades, as a means of reducing the severity of clinical mastitis. Our study objective was to evaluate the effect of 2 commercially available vaccines on clinical, behavioral, and antibody response following Escherichia coli intramammary challenge in cows near peak lactation. Cows $(\mathrm{n}=$ 12 per group) were vaccinated with vaccine 1 (V1) or vaccine 2 (V2) at dry-off, $21 \mathrm{~d}$ pre-calving, and $14 \mathrm{~d}$ post-calving. Twelve cows served as unvaccinated controls (CTL). Cows were challenged with E. coli in a rear quarter at approximately $100 \mathrm{~d}$ in milk. Milk samples were collected pre- and post-challenge to enumerate $E$. coli and determine somatic cell count. Serum was collected before each vaccination and at d $0,1,2,3,6,30$, and 60 relative to challenge, to study antibody response. Milk IgA and tumor necrosis factor- $\alpha$ concentrations were determined in whey. Vaginal temperature, cow activity, and milk yield and components were monitored post-challenge. Bacterial count, somatic cell score, milk yield and component decline, vaginal temperature, activity measures, and antibody and cytokine response were analyzed for treatment differences. The effects of parity, breed, and a repeated measure of time were also tested. Seven cows had to be removed from the study post-challenge for antibiotic treatment (CTL and V1, $\mathrm{n}=3$ each; V2, $\mathrm{n}=1$ ), 2 of which were euthanized (both CTL). Vaccinated cows exhibited fever (vaginal temperature $\left.\geq 39.4^{\circ} \mathrm{C}\right) 3 \mathrm{~h}$ earlier than CTL cows, but we found no differences between treatments for bacterial count, somatic cell score, or milk yield reduction.

Received February 27, 2019.

Accepted August 22, 2019.

*Corresponding author: Nicole.Steele@dairynz.co.nz
Vaccinated cows spent more time lying per rest bout $2 \mathrm{~d}$ post-challenge, but total daily lying time was not different from CTL cows during the $7 \mathrm{~d}$ post-challenge. The vaccines differed in antibody response: V1 cows had greater serum $\operatorname{IgG}_{1}$ and $\operatorname{IgG}_{2}$ post-challenge. A parity effect was also evident: primiparous cows had lower bacterial counts, somatic cell score and a smaller milk yield decline than multiparous cows, but also had lower antibody production. Immunization with either $\mathrm{J} 5$ bacterin did not reduce clinical signs of mastitis in cows challenged at $100 \mathrm{~d}$ in milk, demonstrating that the effects of J5 vaccination had diminished at peak lactation.

Key words: mastitis, immune response, J5 bacterin

\section{INTRODUCTION}

Coliforms such as Escherichia coli and Klebsiella pneumoniae are frequent causes of bovine mastitis. The severity of infection can range from a mild or moderate case, with short-term effects on milk production and milk quality and a relatively quick recovery, to a severe systemic illness, which can lead to death. Approximately $25 \%$ of cows in a well-managed herd will develop clinical coliform mastitis each year (Hogan and Smith, 2003). A single case of clinical mastitis occurring in the first $30 \mathrm{~d}$ of lactation has been estimated to have a total economic cost of $\$ 444$ (Rollin et al., 2015). As such, the vaccination of dairy cattle with a J5 bacterin has been an approach to reducing the severity of coliform mastitis for the past 30 years (González et al., 1989). In the United States, an estimated $18 \%$ of all dairy operations and $51 \%$ of large dairy herds (>500 cows) have adopted a vaccination program against coliform mastitis (USDA, 2016).

The sudden and acute inflammatory response associated with clinical mastitis caused by coliforms is due to 
LPS, a cell-wall component of gram-negative bacteria released upon bacterial death and a potent immune stimulator. The strain often incorporated in coliform vaccines is E. coli O111:B4 (J5; González et al., 1989), a rough mutant that lacks the O-polysaccharide chains of LPS, exposing the core antigens. Immunization with a J5 bacterin produces cross-reactive antibodies with other coliform pathogens, because the target is a highly conserved region of LPS, providing nonspecific immunity against these pathogens (Dosogne et al., 2002; Chaiyotwittayakun et al., 2004).

Previous studies have demonstrated reduced severity and duration of clinical mastitis in mild (Hogan et al., 1995) and moderate experimentally induced $E$. coli mastitis (Tomita et al., 1998; Hogan et al., 2005), or reduced incidence (González et al., 1989; Hogan et al., 1992b) or severity (Wilson et al., 2008, 2009) of naturally occurring clinical mastitis in cows immunized with a J5 bacterin. In contrast, some authors reported few clinical differences following an E. coli intramammary challenge, but observed an antibody response as a result of vaccination with a J5 bacterin (Smith et al., 1999; Tomita et al., 2000). These differences in responses between studies may have been related to variations in study design, mastitis type (experimental vs. natural), and the specific J5 vaccine protocol used. Hence, cow response to immunization with J5 bacterins across various conditions needs to be characterized to improve the effectiveness of vaccine protocols in reducing the effects of mastitis.

Although most coliform cases occur in early lactation, coliform bacteria can still cause severe illness later in lactation (Hogan and Smith, 2003). Antibody levels to $E$. coli J5 are known to decline over time, so successive vaccinations with the start of each lactation are needed (Wilson et al., 2009). In a field study of naturally occurring clinical mastitis, Wilson et al. (2009) demonstrated a diminished effect of $\mathrm{J} 5$ vaccination as lactation progressed, and milk loss associated with clinical mastitis was similar between vaccinated cows and unvaccinated controls after 75 DIM. Most experimental challenge studies have induced mastitis during the first $30 \mathrm{~d}$ of lactation to evaluate vaccine efficacy; fewer research efforts have considered the longer-term effects of vaccination with a J5 bacterin. Our study objective was to examine the effect of 2 commercially available J5 bacterins on clinical, behavioral, and antibody responses following E. coli intramammary challenge in dairy cows at peak lactation. We hypothesized that compared to unvaccinated controls, vaccinated cows would show less severe signs of clinical mastitis in terms of milk appearance, bacterial count, SCC, and febrile response; fewer changes in lying behavior; and greater antibody production.

\section{MATERIALS AND METHODS}

The experiment was conducted at the Dairy Science Complex-Kentland Farm in Blacksburg, Virginia. All experimental procedures were approved by the Virginia Polytechnic Institute and State University Institutional Animal Care and Use Committee (Protocol \#16-109).

\section{Study Participants}

Approximately 60 d before expected calving, cows and heifers $(\mathrm{n}=65)$ were randomly assigned to 1 of 3 groups: vaccine 1 (V1), vaccine 2 (V2), or unvaccinated controls (CTL). Randomization was performed using the random function in Excel (Microsoft Corp., Redmond, WA). Lactating cows were dried off through abrupt cessation of milking approximately $60 \mathrm{~d}$ before expected calving. A dry-cow antibiotic (300 mg of cephapirin benzathine; TOMORROW, Boehringer Ingelheim Vetmedica Inc., St. Joseph, MO) was administered into each quarter at dry-off. Pregnant dry cows and heifers were housed on pasture during the nonlactating period until 3 wk before their expected calving, when they were moved to a compost-bedded pack barn. After calving, cows were milked twice daily in a double-12 parallel parlor at 12-h intervals and housed in a sand-bedded freestall barn.

\section{Vaccine Administration}

Vaccines were administered subcutaneously in the neck in 3 doses $(5 \mathrm{~mL}$ each), following the manufacturer's recommendations, for cows enrolled in the V1 and V2 groups. Cows in the CTL group received no vaccination. The vaccination schedule for cows receiving the first 2 doses of $\mathrm{V} 1$ and V2 was 60 and $21 \mathrm{~d}$ before calving. At $61 \pm 7 \mathrm{~d}$ (mean $\pm \mathrm{SD}$ ) and $18 \pm$ $5 \mathrm{~d}$ before calving, the first and second vaccines were administered. The third dose of V1 was to be given at $<14$ DIM, and the third dose of V2 was to be given at $>14$ DIM. For V1 cows, the third vaccine was administered at $12 \pm 1 \mathrm{~d}$ postpartum (range 10 to $14 \mathrm{~d}$ ), and for V2 cows, the third vaccine was administered at 15 $\pm 2 \mathrm{~d}$ postpartum (range 13 to $18 \mathrm{~d}$ ).

\section{Cow Selection for Intramammary Challenge}

Of the 65 enrolled cows, 36 were selected for an intramammary challenge with $E$. coli at $102 \pm 15$ DIM (range 72 to $137 \mathrm{~d}$ ). The pre-challenge characteristics of the cows in each of the 3 treatment groups $(n=12$ per group) are described in Table 1. Selected cows were required to have no history of clinical mastitis in the current lactation before challenge, and the quarter to 
Table 1. Pre-challenge characteristics (mean $\pm \mathrm{SD}$ ) and post-trial outcomes of animals randomly assigned to treatments before an Escherichia coli intramammary challenge ${ }^{1}$

\begin{tabular}{lccc}
\hline & \multicolumn{3}{c}{ Treatment } \\
\cline { 2 - 4 } Characteristic & V1 & V2 & CTL \\
\hline Pre-challenge quarter SCS & $0.2 \pm 1.1$ & $0.6 \pm 1.1$ & $0.1 \pm 1.2$ \\
Pre-challenge milk yield (kg/d) & $40.6 \pm 8.8$ & $44.9 \pm 9.9$ & $41.6 \pm 9.5$ \\
Pre-challenge activity (steps/h) & $101 \pm 29$ & $93 \pm 23$ & $108 \pm 42$ \\
Pre-challenge lying time (min/d) & $694 \pm 102$ & $700 \pm 101$ & $649 \pm 142$ \\
Pre-challenge lying bout (no./d) & $14 \pm 5$ & $12 \pm 2$ & $13 \pm 4$ \\
Pre-challenge lying bout duration (min/bout) & $60 \pm 26$ & $60 \pm 14$ & $57 \pm 20$ \\
DIM at challenge (d) & $90 \pm 14$ & $105 \pm 11$ & $111 \pm 14$ \\
Parity (no. of cows) & $2.1 \pm 1.2$ & $2.3 \pm 1.2$ & $2.5 \pm 1.5$ \\
Breed (n) & & 10 & 7 \\
Holstein & 6 & 2 & 5 \\
Jersey & 6 & 1 & 3 \\
Morbidity ${ }^{2}$ (no. of cows) & 3 & 0 & 2 \\
Mortality (no. of cows) & 0 & 11 & 9 \\
Cows completed trial (no.) & 9 & & \\
${ }^{1}$ CTL = unvaccinated control; V1 = vaccine 1; V2 = vaccine 2. & & \\
${ }^{2}$ Morbidity indicates cows that required treatment in the 7 -d post-challenge period, and includes cows that \\
were euthanized.
\end{tabular}

be challenged was required to have a SCC $<100,000$ cells/mL and be clear of any IMI in the 1 wk preceding the challenge. Cows were prescreened for SCC and IMI at $\mathrm{d}-7,-5$, and -3 relative to the challenge, which is described in more detail in a later section.

\section{Intramammary Challenge}

The intramammary challenge strain was E. coli 727 , a well-characterized strain originally isolated from a naturally occurring IMI (Hogan et al., 1995). Previous studies report mild clinical mastitis following intramammary infusion with this strain (Hogan et al., 1992a; Yeiser et al., 2012). The challenge inoculum was prepared using a frozen stock culture streaked for isolation on esculin blood agar and incubated at $37^{\circ} \mathrm{C}$ overnight. A single colony was transferred into $25 \mathrm{~mL}$ of trypticase soy broth and grown at $37^{\circ} \mathrm{C}$ in a shaking incubator $(200 \mathrm{rpm})$ for $12 \mathrm{~h}$ to reach stationary phase. The broth culture was centrifuged at 1,600 $\times$ $g$ for $10 \mathrm{~min}$ at $4^{\circ} \mathrm{C}$, and the pellet resuspended in 20 $\mathrm{mL}$ of PBS (1\% solution made from Dulbecco's PBS 10\%; Life Technologies Corp., Grand Island, NY). The broth culture was adjusted to 70 to $72 \%$ transmission at $540 \mathrm{~nm}$, and 6 serial 10-fold dilutions in PBS were made to achieve approximately $100 \mathrm{cfu} / \mathrm{mL}$ in the final dilution. The concentration was determined by dropplating $25 \mu \mathrm{L}$ in triplicate on esculin blood agar and counting colonies after overnight incubation at $37^{\circ} \mathrm{C}$. Before infusion, teats were cleaned with cotton balls soaked in $70 \%$ ethanol. The challenge dose $(1 \mathrm{~mL})$ was administered in 1 rear quarter via a teat cannula (Jor- gensen Laboratories Inc., Loveland, CO) immediately following the afternoon milking.

\section{Sampling Schedule}

For all cows enrolled in the study $(\mathrm{n}=65)$ and for those selected for intramammary challenge $(n=36)$, the sampling schedule was the same regardless of treatment group (V1, V2, or CTL).

Blood Sample Collection for Antibody Determination. At approximately d -60 , d -21 , and d 14 relative to calving, blood was collected from the caudal vein of all enrolled animals $(\mathrm{n}=65)$. For V1 and V2 cows, blood was collected before vaccine administration. For cows selected for intramammary challenge (n $=36$ ), blood was also collected at $0,1,2,3,6,30$, and $60 \mathrm{~d}$ relative to challenge. After collection, blood was centrifuged $(700 \times g)$ for $15 \mathrm{~min}$, and 4 aliquots of serum were stored at $-20^{\circ} \mathrm{C}$ for subsequent analysis.

Milk Samples for Bacterial Identification. Foremilk $(5 \mathrm{~mL})$ was aseptically collected from all quarters of the 65 enrolled animals at $-7,-5$, and -3 d relative to the challenge to determine IMI status for cow selection for intramammary challenge. For cows receiving the intramammary challenge $(\mathrm{n}=36)$, foremilk was aseptically collected from all quarters immediately before the challenge (d 0$)$, and $1,2,3,4,5,6,7,30$, and $60 \mathrm{~d}$ post-intramammary challenge (PIC) for standard microbiological analyses. Bacterial identifications were completed following National Mastitis Council guidelines (Middleton et al., 2017). Briefly, quarter milk samples were streaked on a quadrant of esculin blood 
agar and a half of MacConkey agar and incubated for $48 \mathrm{~h}$ at $37^{\circ} \mathrm{C}$. Growth was recorded at 24 and $48 \mathrm{~h}$. Biochemical tests were used to confirm bacterial species.

Milk Samples for SCC Determination. Milk (30 $\mathrm{mL}$ ) was collected from all quarters of the 65 enrolled animals at $-7,-5$, and -3 d relative to the intramammary challenge to determine the quarter SCC required for cow selection for the challenge. For the 36 cows receiving the intramammary challenge, milk was collected from all quarters at d $0,1,2,3,4,5,6,30$, and 60 $\mathrm{d}$ PIC, and from the challenged quarter of all animals at $6,12,15,18$, and $21 \mathrm{~h}$ PIC. Samples were sent to the DHIA laboratory (United DHIA, Radford, VA) for SCC quantification using a Fossomatic FC (FOSS North America, Eden Prairie, MN). Milk samples that were grossly clinically infected were diluted in PBS before being sent to the laboratory, and SCC was calculated using the dilution factor.

Milk Samples for Bacterial Enumeration. Bacterial enumeration was completed for milk from only the challenged quarter of all challenged animals at 6 , $12,15,18$, and $21 \mathrm{~h}$ and $1,2,3,4,5,6$, and $7 \mathrm{~d}$ PIC. Five serial 10-fold dilutions were made in a 96-well plate for each milk sample in duplicate, using PBS as the diluent. For each dilution and duplicate, 4 replicates of $10 \mu \mathrm{L}$ each were dropped on the surface of MacConkey agar and, after overnight incubation at $37^{\circ} \mathrm{C}$, the number of colonies were counted at the appropriate dilution and averaged. Pour plates were used for the lower limit of detection, where $1 \mathrm{~mL}$ and $0.1 \mathrm{~mL}$ of undiluted milk were dispensed in $12 \mathrm{~mL}$ of liquid MacConkey agar in duplicate, and colonies were counted after overnight incubation at $37^{\circ} \mathrm{C}$. The bacterial counts were expressed as the number of colony-forming units per milliliter of milk.

Milk Samples for Antibody and Cytokine Determination. Immediately before challenge (d 0) and at $1,2,3$, and 6 PIC, foremilk (30 $\mathrm{mL})$ was aseptically collected from the challenged quarter only for milk antibody and cytokine determination. Milk samples were centrifuged $(2,500 \times g)$ for $30 \mathrm{~min}$ at $4^{\circ} \mathrm{C}$, and the fat layer was removed with a spatula. Four aliquots of skim milk were made in microcentrifuge tubes and stored at $-20^{\circ} \mathrm{C}$.

\section{Milk Appearance, Yield, and Composition}

Milk appearance was recorded to assess clinical status at the time of the milk sample collection on a scale of 1 to 5 , as previously described by Hogan et al. (1995): $1=$ normal milk and quarter; $2=$ normal quarter and slight alterations to milk (e.g., few flakes); 3 = abnormal quarter (hot, swollen, or both) and nor- mal to slightly altered milk (few flakes), or, normal quarter and abnormal milk (clots, clumps, changes in milk color); $4=$ abnormal quarter and milk; and $5=$ swollen quarter, abnormal milk, and systemic signs of infection (elevated rectal temperature, depression, dullness). A quarter was considered clinically mastitic if the milk appearance and mammary gland was scored $\geq 3$. Milk yield $(\mathrm{kg})$ was measured at each milking by an inline milk meter (Afimilk Ltd., Kibbutz Afikim, Israel) starting $1 \mathrm{wk}$ before the challenge and ending 60 d PIC. Milk composition, including protein, lactose, and fat percentages, were measured by an inline milk analyzer (AfiLab; Afimilk Ltd.), which has been previously validated (Kaniyamattam and De Vries, 2014).

\section{Body Temperature}

Vaginal temperature was recorded at 15-min intervals using a temperature data logger (Star Oddi, Gardabaer, Iceland). Temperatures were averaged every $6 \mathrm{~h}$ in the first $12 \mathrm{~h}$ PIC, every $3 \mathrm{~h}$ for the next $12 \mathrm{~h}$, and daily thereafter for the $7 \mathrm{~d}$ period PIC, to match the sampling regimen for the challenged quarter. For animal monitoring, rectal temperatures were recorded on the same schedule as sampling of the challenged quarter, and daily thereafter for the 7 -d experimental period.

\section{Cow Behavior}

Cow behavior, including activity (steps/h), lying time (min/d), lying bouts (bouts/d) and average lying bout duration (min/bout), was monitored using an accelerometer (AfiAct II; Afimilk Ltd.) attached to a rear leg of each cow. Data were transmitted at each milking to the herd management software (AfiFarm, Afimilk Ltd.) for data storage. Behavioral data were summarized into daily periods, beginning at $-1 \mathrm{~d}$ relative to the challenge and ending $7 \mathrm{~d}$ PIC. A daily period consisted of $24 \mathrm{~h}$ relative to the time of day that the challenge occurred, so that $\mathrm{d}-1$ represented the $24 \mathrm{~h}$ immediately preceding the challenge, and d 0 represented the $24 \mathrm{~h}$ immediately following the challenge, and so on.

\section{Determination of Antibody and Cytokine Concentrations}

Relative antibody concentrations to E. coli J5 wholecell antigens in serum and milk were determined by ELISA (Tyler et al., 1991). Isotypes assayed in serum were $\operatorname{IgG} G_{1}, \operatorname{IgG}_{2}, \operatorname{IgA}$, and $\operatorname{IgM}$ at the following time points: $\mathrm{d}-60, \mathrm{~d}-21$, and $\mathrm{d} 14$ relative to calving, and d $0,1,2,3,6,30$, and 60 relative to the challenge. An IgA assay was completed in milk collected at d $0,1,2$, 
$3,6,30$, and 60 relative to the challenge. For preparation of the whole cell solution for coating plates, $E$. coli 727 was grown from stock culture to stationary phase, as for the intramammary challenge preparation. The culture was checked for sterility, formalin-fixed, and checked for viability. The whole cell solution was diluted in PBS with $0.005 \%$ phenol, adjusted to $25 \%$ transmission at $610 \mathrm{~nm}$, and stored at $-20^{\circ} \mathrm{C}$. Flat-bottomed 96-well microtiter plates (Immulon-1B, Thermo Scientific, Rochester, NY) were coated with $100 \mu \mathrm{L}$ of whole-cell stock solution in each well, sealed, and incubated overnight at $37^{\circ} \mathrm{C}$. The remaining solution was decanted, and plates were washed 3 times with the plate wash solution (PBS $+0.1 \%$ Tween 20 (Sigma-Aldrich, St. Louis, MO). Each 96-well plate included a negative control (fetal bovine serum; Atlanta Biologicals, Lawrenceville, GA) and a positive control (serum from a J5-immunized cow), and each sample was tested in triplicate. The same cow's serum was used as the positive control in all assays. Serial dilutions of sample and controls in blocking buffer (PBS $+0.05 \%$ Tween 20) were prepared in an untreated plate, and $100 \mu \mathrm{L}$ from each well was transferred to the coated plate. The plate was incubated for at least $30 \mathrm{~min}$ at $37^{\circ} \mathrm{C}$ to allow any antibody in the sample to bind to the coated antigen. The plate was washed 3 times, with a 3 min incubation step between the second and third washes. Secondary antibodies for $\operatorname{IgG}_{1}, \operatorname{IgG}_{2}$ [sheep anti-bovine $\operatorname{IgG}_{1} / \operatorname{IgG}_{2}$ secondary antibody, horseradish peroxidase (HRP) conjugated; Invitrogen, Rockford, IL], IgA (sheep anti-bovine IgA HRP conjugated; Bethyl Laboratories Inc., Montgomery, TX), and IgM (rabbit anti-bovine IgM HRP conjugated; Bethyl Laboratories Inc.) were prepared to working concentrations according to manufacturers' recommendations (sheep anti-bovine IgG1 secondary antibody, HRP: https://www.thermofisher .com/antibody/product/Sheep-anti-Bovine-IgG1 -Secondary-Antibody-Polyclonal/PA1-84658; sheep anti-bovine IgG2 secondary antibody, HRP: https:// www.thermofisher.com/antibody/product/Sheep-anti -Bovine-IgG2-Secondary-Antibody-Polyclonal/PA1 -84661; bovine IgA antibody, https://www.bethyl.com/ product/pdf/A10-131P.pdf; bovine IgM antibody, https://www.bethyl.com/product/pdf/A10-100P.pdf), and $100 \mu \mathrm{L}$ was added to each well before a $30 \mathrm{~min}$ incubation at $37^{\circ} \mathrm{C}$. Seven plate washes followed the incubation step, with 3 min incubation steps at room temperature between the fourth, fifth, and sixth wash. Next, $100 \mu \mathrm{L}$ of substrate (1-Step ABTS; ThermoFisher Scientific, Rockford, IL) was added to each well and left to develop at room temperature. Stopping reagent (1\% SDS, from 10\% solution; Fisher Scientific, Fair Lawn, NJ) was added after a set period, ranging from 6 to
25 min, depending on which antibody was being assayed. Optical density (OD) was read at $410 \mathrm{~nm}$, and triplicates within each dilution for each sample were averaged. The most appropriate dilution was selected at the highest dilution within the linear phase (i.e., OD value between 0.3 and 0.8 ). Samples were repeated if the intra-assay coefficient of variation was $>15 \%$. Similarly, plates were repeated if the inter-assay coefficient of variation for the positive control on each plate exceeded $15 \%$. Sample OD were expressed relative to the positive control OD in arbitrary units.

Tumor necrosis factor- $\alpha$ ( TNF $\boldsymbol{\alpha})$ was quantified (pg/ $\mathrm{mL}$ ) from milk samples collected on d $0,1,2,3$, and 6 relative to the intramammary challenge using a bovine ELISA (DuoSet ELISA, R\&D Systems, Inc., Minneapolis, MN) according to the manufacturer's instructions (https://www.rndsystems.com/products/bovine -tnf-alpha-duoset-elisa_dy2279\#assay-procedure). In brief, flat-bottom, high-binding 96-well plates were coated with $100 \mu \mathrm{L}$ of goat anti-bovine TNF $\alpha$ capture antibody, diluted in PBS, and were incubated overnight at room temperature. Coated plates were aspirated and washed 3 times $(0.05 \%$ Tween 20 in PBS). Next, plates were blocked for $1 \mathrm{~h}$ with $300 \mu \mathrm{L}$ of the reagent diluent (5\% Tween 20 in PBS), then aspirated and washed 3 times. Standards and milk samples were loaded onto the plate in duplicate. Using 2-fold dilutions in reagent diluent, a 7-point recombinant bovine $\mathrm{TNF} \alpha$ standard was loaded onto each plate; the highest concentration was $8,000 \mathrm{pg} / \mathrm{mL}$, and the lowest was $125 \mathrm{pg} / \mathrm{mL}$. Following a 2-h incubation at room temperature, plates were aspirated, washed 3 times, and $100 \mu \mathrm{L}$ of biotinylated goat anti-bovine $\mathrm{TNF} \alpha$ detection antibody, diluted in reagent diluent with $2 \%$ normal goat serum, was added to each well. Plates were again incubated for $2 \mathrm{~h}$ at room temperature, aspirated, and washed 3 times. Next, $100 \mu \mathrm{L}$ of streptavidin-HRP, diluted in reagent diluent, was added to each well and incubated for 20 min at room temperature in the absence of light. Following another step of washing 3 times, $100 \mu \mathrm{L}$ of the substrate solution (1:1 mixture of $\mathrm{H}_{2} \mathrm{O}_{2}$ and tetramethylbenzidine) was added to each well and incubated in the dark for $20 \mathrm{~min}$ at room temperature. Finally, $50 \mu \mathrm{L}$ of the stop solution $\left(2 \mathrm{~N} \mathrm{H}_{2} \mathrm{SO}_{4}\right)$ was added to each well, and the OD was determined at $450 \mathrm{~nm}$ using a microplate reader. Duplicate readings were averaged, and a 4-parameter logistic regression standard curve was used to determine the quantity of TNFo in each sample. If the OD reading from the milk sample did not fall on the standard curve, the milk sample was diluted in reagent diluent, repeated, and quantified appropriately using the dilution factor. Samples were also repeated if the intra-assay CV was $>15 \%$. 


\section{Sample Size Determination}

To estimate the number of animals required to achieve $80 \%$ power, a power analysis was performed before the trial began for 3 of the outcomes investigated. The differences between vaccinated and control cows in bacterial count, milk yield percentage of pre-challenge yields, and $\operatorname{IgG}_{1}$ concentrations were estimated from the literature (Hogan et al., 1992a; Tomita et al., 2000). To detect a difference of $1.3 \mathrm{log} \mathrm{cfu} / \mathrm{mL}$ at peak bacterial growth, using a standard deviation of $0.95 \log \mathrm{cfu} / \mathrm{mL}$ (Hogan et al., 1992a), 12 cows per group were necessary to achieve $80 \%$ power with a type I error rate of 0.05 . Similarly, a $13 \%$ difference in percent of pre-challenge milk yield between controls and vaccinates $1 \mathrm{~d}$ PIC (SD $=9.5 \%$; Hogan et al., 1992a) could be detected with 12 cows per group. Fewer cows were needed per group (n $=3$ ) to detect a difference of $2.2 \log \operatorname{IgG}_{1}$ titers ( $\mathrm{SD}=$ 0.57; Tomita et al., 2000).

\section{Statistical Analysis}

Bacterial counts from the challenged quarter were transformed into $\log _{10} \mathrm{cfu} / \mathrm{mL}$. Quarter SCC was transformed to SCS (Ali and Shook, 1980), which uses a base-2 log-transformation $\left[\mathrm{SCS}=\log _{2}(\mathrm{SCC} / 100,000)+\right.$ $3]$. Milk yield and milk components PIC were expressed as the percentage of the 7-d mean of these measures from the week preceding the challenge (Hogan et al., 1992a). Relative OD for all antibody assays and TNF $\alpha$ concentration $(\mathrm{pg} / \mathrm{mL})$ were transformed to a natural logarithm (ln). For all models, residuals were analyzed for normality and outliers. Outliers were removed if the studentized residuals exceeded 4 .

Mortality and morbidity rates were analyzed using the GENMOD procedure in SAS (version 9.4; SAS Institute Inc., Cary, NC) with the main effects of treatment (V1, V2, CTL), parity (multiparous or primiparous) and breed (Holstein or Jersey) offered into the model, and pre-challenge milk yield used as a covariate. For the mortality and morbidity models, a binary outcome of 0 or 1 were possible, with 0 indicating survival or successful completion of the trial without treatment, and 1 indicating death or treatment required, respectively.

Vaginal temperature, counts (log cfu/mL), SCS, milk appearance, relative milk yield and components, behavioral variables, and antibody and cytokine responses were analyzed for treatment differences using the GLIMMIX procedure in SAS (SAS Institute Inc.). Variables offered into each of the models included the main effects of treatment, parity, breed, a repeated measure (period), and associated 2-way interactions, with cow modeled as a random effect. For the behavioral responses, including steps per hour, number of rest bouts, minutes spent lying, and average rest duration, the day preceding the challenge was used as a covariate to account for cow differences for those behaviors. Six cows did not have covariate data and were not included in the behavioral models. The antibody models included $\ln$ serum $\operatorname{IgG}_{1}, \operatorname{IgG}_{2}$, the ratio of $\operatorname{IgG}_{1}$ to $\mathrm{IgG}_{2}, \operatorname{IgM}$, and $\operatorname{IgA}$, and milk IgA. The ln relative OD of each antibody at $\mathrm{d}-60$, before initial vaccination, was used as a covariate for each respective serum antibody model to account for differences in individual cows before beginning the vaccination schedule for this study. We checked DIM as a covariate for milk yield, milk component, behavioral and antibody models, but it was not significant. Repeated measures, such as day or period, depending on the response variable, were modeled using the autoregressive error structure, and the Kenward-Roger procedure was used to approximate degrees of freedom. Backward elimination was used to eliminate nonsignificant terms from highest to least significant, until all variables were significant $(P \leq 0.05)$; however, the main effect of treatment was forced into the model, regardless of significance. Main effects were retained if $P \leq 0.05$ or if the main effect was involved in a significant interaction term. Least squares means and standard errors for each model were estimated for significant variables, and Tukey-adjusted $P$-values were declared significant at $P \leq 0.05$.

\section{RESULTS}

Thirty-six animals received the intramammary challenge of $113 \pm 13 \mathrm{cfu} / \mathrm{mL}$ of $E$. coli. Table 1 provides a summary of the challenged animals in each treatment group with respect to pre-challenge characteristics, breed, parity, morbidity, and mortality. Seven cows were removed from the study because of antibiotic treatment during the 7 -d post-challenge period: 3 each from the V1 and CTL groups, and 1 from the V2 group. Of these, 2 CTL cows were euthanized. The need for veterinary attention was determined without regard to vaccination status. Data collection from cows ceased at the time they were treated and removed from the study, but data collected before their removal remained in the analyses. Treatment did not have a significant effect on mortality rate $(P=0.10)$ or morbidity rate in the 7 d PIC $(P=0.08)$. The morbidity rate was associated with pre-challenge milk yield $(P<0.01)$ and was higher in multiparous cows than in primiparous heifers $(P=$ $0.02)$. 


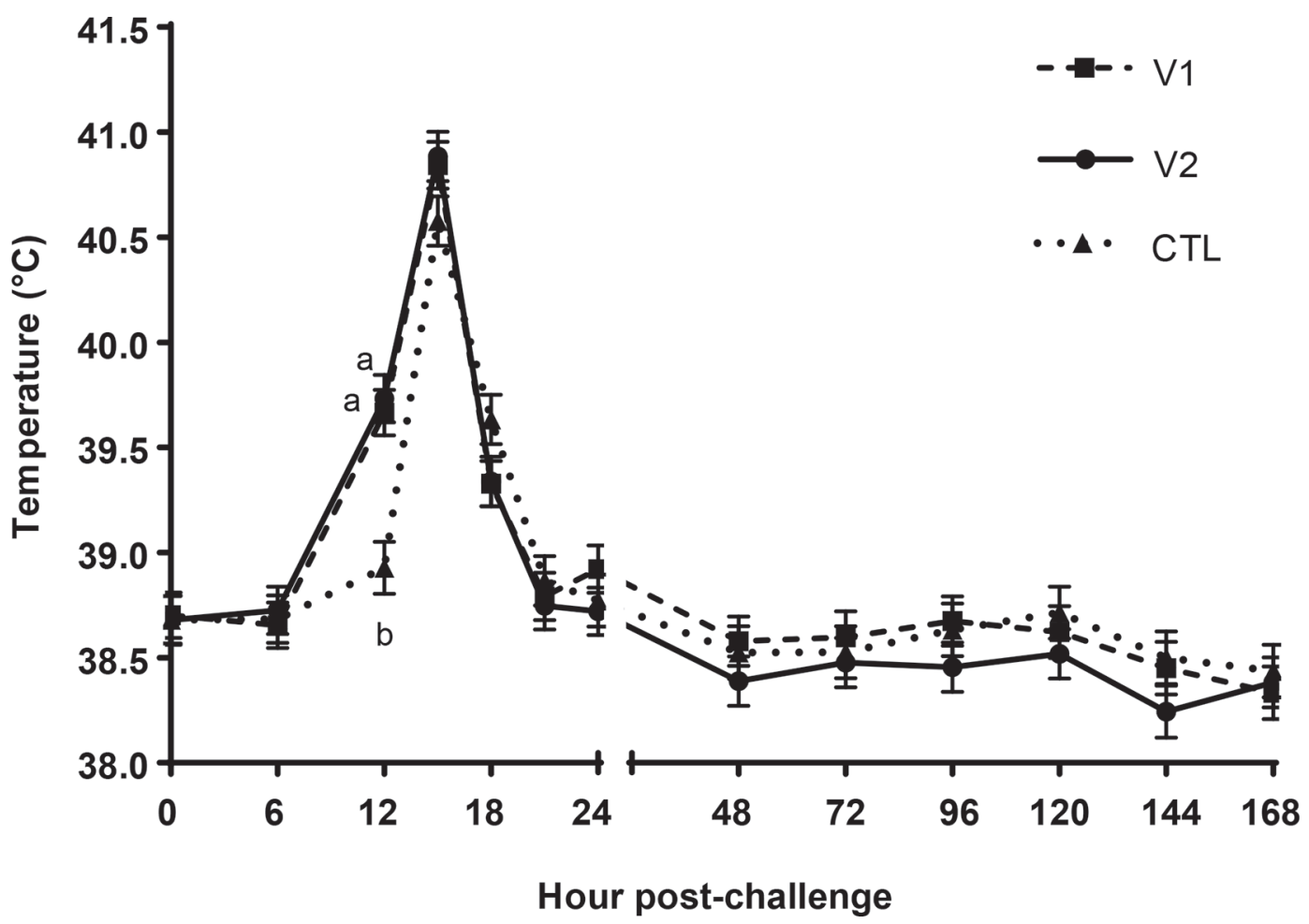

Figure 1. Least squares means $( \pm \mathrm{SEM})$ of vaginal temperature in the hours following an intramammary challenge with Escherichia coli for cows vaccinated with vaccine 1 (V1) or vaccine 2 (V2), or unvaccinated controls (CTL). Different letters (a, b) denote a significant difference $(P<0.05)$ between treatments within hour.

\section{Febrile Response}

Mean vaginal temperatures were elevated $\left(\geq 39.4^{\circ} \mathrm{C}\right)$ at $12 \mathrm{~h}$ PIC for both $\mathrm{V} 1\left(39.7^{\circ} \mathrm{C} \pm 0.1\right)$ and $\mathrm{V} 2\left(39.7^{\circ} \mathrm{C}\right.$ $\pm 0.1)$ cows, whereas CTL cows had lower temperatures at this time $\left(38.9^{\circ} \mathrm{C} \pm 0.1 ; P<0.01\right.$; Figure 1$)$. Temperatures peaked at $15 \mathrm{~h}$ PIC, returning to the normal range by $21 \mathrm{~h}$ PIC. We observed no differences in body temperature between groups from $15 \mathrm{~h} \mathrm{PIC}$, or for the remainder of the 7-d post-challenge period.

\section{Milk-Associated Parameters}

All but 1 cow developed clinical mastitis (score $\geq 3$ ) in the challenged quarter by $12 \mathrm{~h}$ PIC; the remaining cow had visible clinical mastitis by $15 \mathrm{~h}$ PIC. Clinical signs of mastitis remained apparent in challenged quarters until $5 \mathrm{~d}$ PIC, when the average milk appearance score decreased below 3 . We observed a parity effect on milk appearance: multiparous cows took $2 \mathrm{~d}$ longer to return to normal milk appearance (score 1 or 2), with higher scores than primiparous heifers from 3 to $7 \mathrm{~d}$ PIC $(P<0.01$; Table 2).

Bacterial counts and SCS did not differ between treatment groups for the study period, but we did ob- serve a parity $\times$ period interaction for both responses (Table 2). Peak E. coli concentration was reached at 12 h PIC for both multiparous and primiparous animals, but multiparous cows had significantly higher bacterial counts than primiparous heifers from $15 \mathrm{~h}$ to $5 \mathrm{~d}$ PIC $(P<0.05$; Figure 2A). The SCS peaked between $18 \mathrm{~h}$ and $2 \mathrm{~d}$ PIC, and began to decline by $3 \mathrm{~d}$ PIC; however, it did not return to pre-challenge levels in the $60 \mathrm{~d}$ following the challenge, especially for multiparous animals. Primiparous heifers had higher peak SCS at $24 \mathrm{~h}$ PIC, but their SCS declined faster, with significantly lower SCS at d 3, 6, 7, 30 and 60 PIC, compared with multiparous cows $(P<0.05$; Figure $2 \mathrm{~B})$. We also detected a breed $\times$ period interaction for SCS; initially, Jersey cows had lower SCS at $15 \mathrm{~h}$ PIC, but later, their SCS was significantly higher than that of Holsteins at d 1 and d 60 PIC $(P=0.01$; data not shown $)$.

We found no treatment differences in milk yield response following the intramammary challenge with $E$. coli. In the first $24 \mathrm{~h}$ PIC, average milk yield across all challenged animals declined to $62 \%$ of the $7 \mathrm{~d}$ pre-challenge baseline, with the largest decline occurring at 2 d PIC, when cows produced $49 \%$ of their pre-challenge milk yield. We observed a steady recovery in milk yield, reaching $86 \%$ of pre-challenge levels by $7 \mathrm{~d}$ PIC, and 
STEELE ET AL.

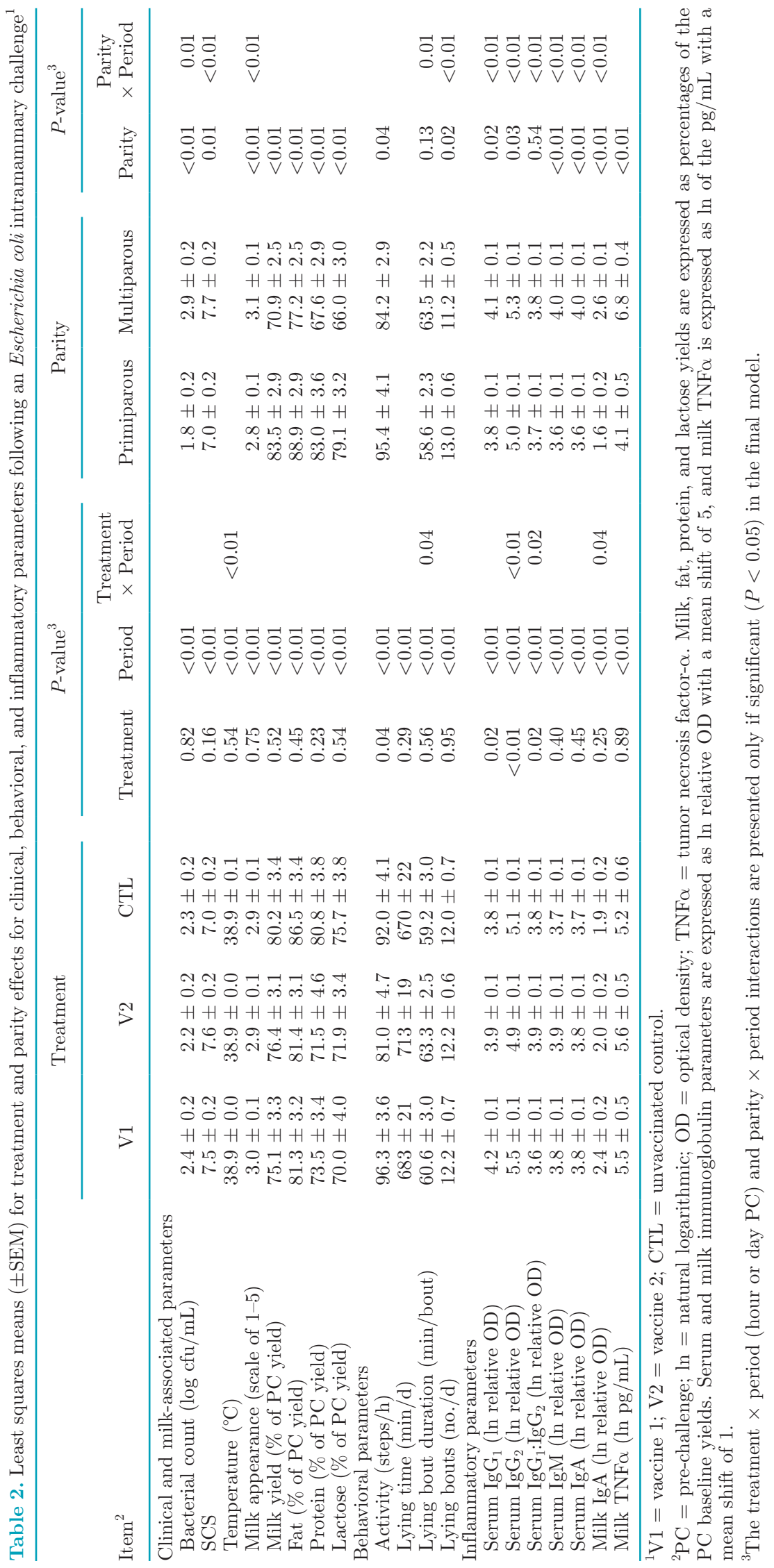



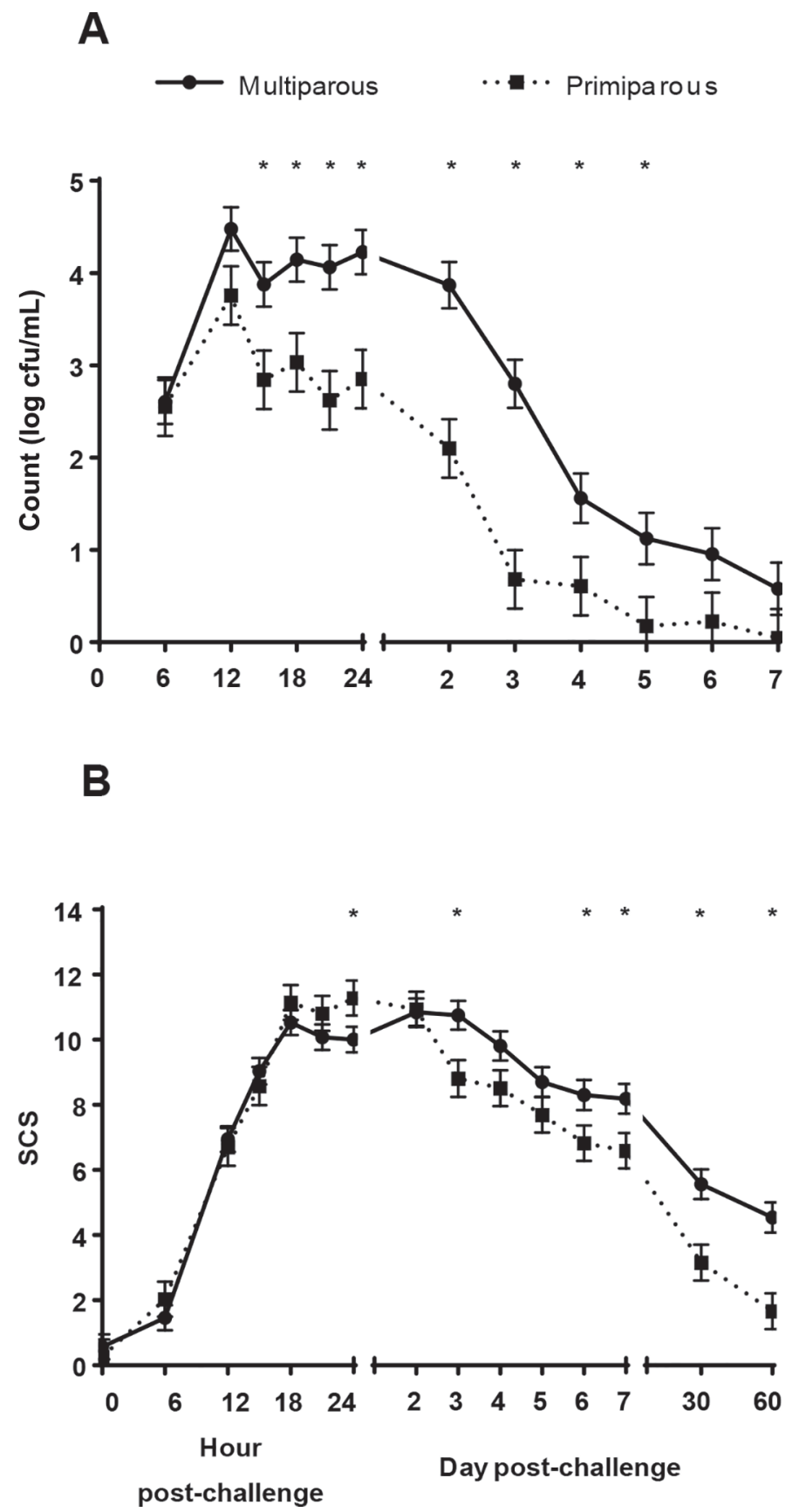

Figure 2. Least squares means $( \pm \mathrm{SEM})$ of multiparous and primiparous cows for (A) bacterial count (log cfu $/ \mathrm{mL})$ and (B) SCS in the hours and days following an intramammary challenge with Escherichia coli. *Significant difference $(P<0.05)$ between parities within time.

93 to $94 \%$ by 30 and 60 d PIC (Figure 3). Parity was significantly associated with the milk yield response to the challenge: multiparous cows had a greater decline in milk yield than primiparous heifers $(P<0.01$; Table 2$)$.

Milk components, including fat, protein and lactose yields, were not affected by treatment group, but de- clined for $2 \mathrm{~d}$ following intramammary challenge and recovered steadily thereafter (Figure 3). Similar to its effects on milk yield, parity also had an effect on the 3 milk components tested, as multiparous cows had a greater decline in yields (relative to pre-challenge baseline milk fat, protein, and lactose yields) than primiparous heifers (Table 2). We observed significant treatment $\times$ parity and treatment $\times$ breed interactions for milk protein production. Multiparous cows treated with V1 had a greater reduction in milk protein yield $(55.9 \pm 5.8 \%$ of pre-challenge protein yield) than multiparous CTL cows $(77.8 \pm 4.5 \% ; P=0.02)$. Holstein cows treated with V1 showed more of a decline in milk protein production $(64.7 \pm 5.4 \%$ of the pre-challenge baseline yield) over the 7-d PIC than V2 Holstein cows $(80.4 \pm 3.6 \% ; P=0.05)$.

\section{Behavioral Parameters}

For the behavioral measures, the respective 1-d pre-challenge covariates were significant in all models, including step activity, lying time, lying bout duration, and number of lying bouts. Treatment and parity least squares means and interactions with period are presented in Table 2. Animals vaccinated with V1 or V2 spent more time lying per bout than CTL animals on $\mathrm{d}$ 2 PIC $(P=0.01$; Figure 4$)$. We observed a treatment $\times$ parity interaction for lying bout duration: multiparous V1 cows spent more time lying per bout than multiparous CTL cows $(70.7 \pm 4.9$ vs. $56.1 \pm 3.5 \mathrm{~min} /$ bout; $P=0.05)$. A breed $\times$ treatment interaction indicated that Jersey cows treated with V2 were less active than V1 Jersey cows $(P=0.01$; Figure $5 \mathrm{~A})$. Primiparous heifers were more active than multiparous cows $(P$ $=0.04$; Table 2 ). We observed a treatment $\times$ parity interaction for the number of lying bouts per day: primiparous heifers treated with $\mathrm{V} 1$ had more lying bouts than V2 and CTL heifers $(P<0.01$; Figure 5B). We observed the opposite trend for multiparous cows: V1 cows had fewer lying bouts than V2 and CTL cows $(P$ $\leq 0.01$; Figure 5B). Lying time was not associated with treatment or parity (Table 2 ).

\section{Inflammatory Parameters}

The respective serum antibody level measured before the first vaccination ( $\mathrm{d}-60$ relative to calving) was a significant covariate in the $\operatorname{IgG}_{1}, \operatorname{Ig} G_{2}, \operatorname{Ig} A$, and IgM models. Serum $\operatorname{IgG}_{1}$ concentration (i.e., relative OD) differed between treatment groups $(P<0.05)$ and tended to differ between treatments over time $(P=$ 0.09; Table 2). The serum $\operatorname{IgG}_{1}$ concentration in $\mathrm{V} 1$ cows was greater than in CTL cows $(P<0.05$; Figure 


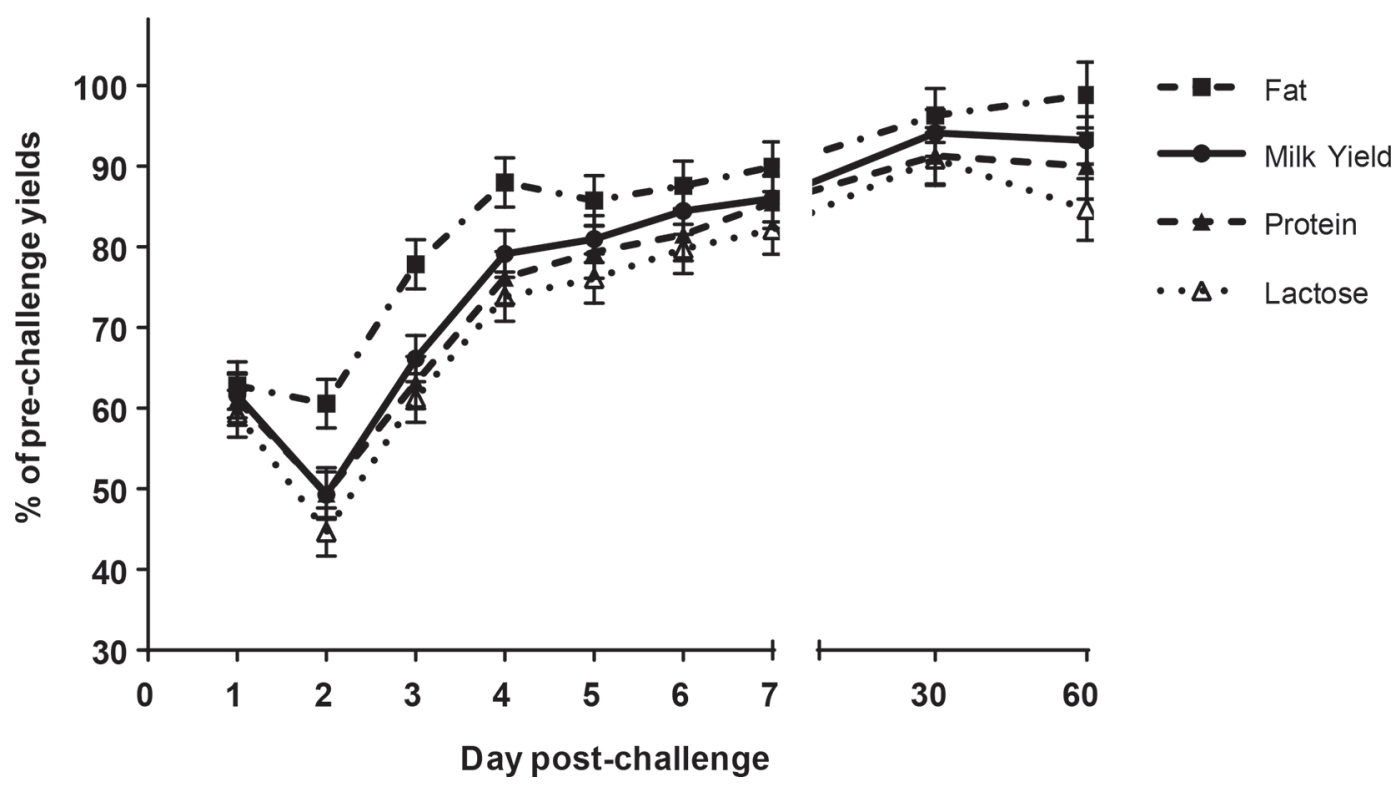

Figure 3. Least squares means $( \pm \mathrm{SEM})$ of the percent of pre-challenge yields $(\mathrm{kg})$ for milk yield, milk fat, milk protein, and milk lactose in the $60 \mathrm{~d}$ following an intramammary challenge with Escherichia coli. No significant differences were found between treatments $(P>0.05)$.

6A). Multiparous cows had greater serum $\operatorname{IgG}_{1}$ levels than primiparous heifers at $\mathrm{d}-21$ relative to calving and at $\mathrm{d} 6,30$, and $60 \mathrm{PIC}(P<0.05$; Figure $7 \mathrm{~A})$.

Serum $\operatorname{IgG}_{2}$ concentration differed between treatment groups $(P<0.01)$ and between treatments over time $(P<0.01$; Table 2$)$. Animals vaccinated with V1 had more serum $\mathrm{IgG}_{2}$ than $\mathrm{V} 2$ and CTL animals at 14 DIM (before the third vaccination; $P<0.01$ ) and at $\mathrm{d}$

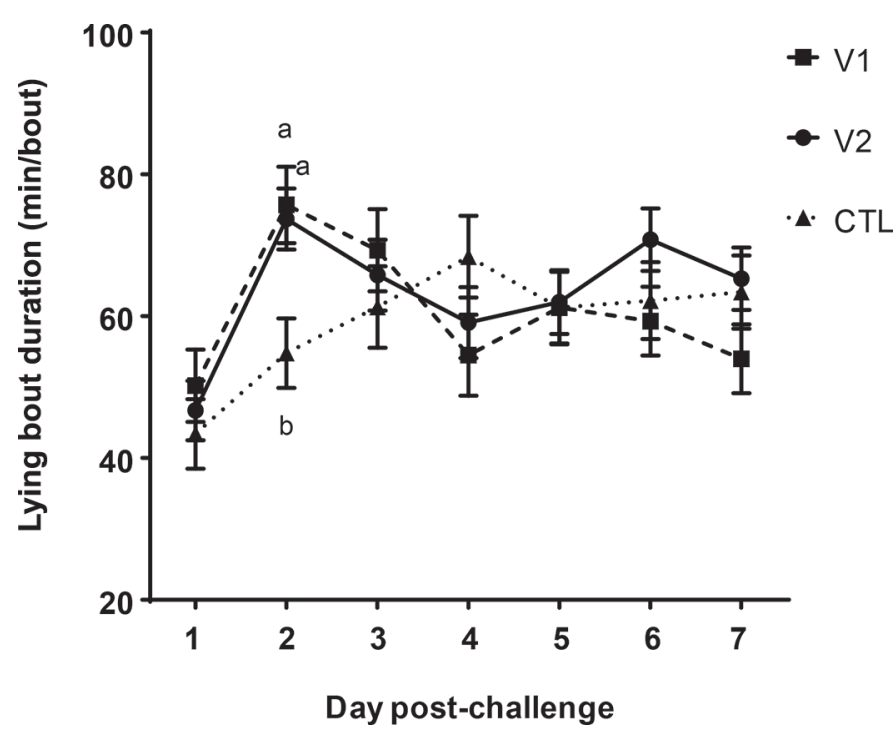

Figure 4. Least squares means ( \pm SEM) of lying bout duration (min/bout) in the $7 \mathrm{~d}$ following an intramammary challenge with Escherichia coli for cows vaccinated with vaccine 1 (V1) or vaccine 2 (V2), or unvaccinated controls (CTL). Different letters $(\mathrm{a}, \mathrm{b})$ denote a significant difference $(P<0.05)$ between treatments within day.
0 , immediately before the challenge $(P \leq 0.06$; Figure $6 \mathrm{~B})$. These higher serum $\operatorname{IgG}_{2}$ levels were maintained in $\mathrm{V} 1$ cows for all time points in the $60 \mathrm{~d}$ PIC, compared with V2 cows $(P<0.05)$. Serum $\operatorname{IgG}_{2}$ concentrations in $\mathrm{V} 1$ cows were also greater than in CTL cows at $\mathrm{d}$ 1,30 , and 60 PIC $(P<0.05)$. At d 6 PIC, serum $\operatorname{IgG}_{2}$ concentrations in CTL cows exceeded that of V2 cows $(P<0.01)$. Multiparous cows had greater serum $\operatorname{IgG}_{2}$ levels than primiparous heifers at $\mathrm{d} 6,30$, and 60 PIC $(P<0.01$; Figure 7B). Across all time points, serum $\mathrm{IgG}_{2}$ levels in Holsteins were similar, regardless of parity, whereas multiparous Jersey cows had greater serum $\mathrm{IgG}_{2}$ levels than primiparous Jersey heifers $(P<0.01$; data not shown). Multiparous Jersey cows also had higher serum $\operatorname{IgG}_{2}$ concentrations than their Holstein multiparous counterparts $(P<0.05$; data not shown). The ratio of serum $\operatorname{IgG}_{1}$ to $\operatorname{IgG}_{2}$ in $\mathrm{V} 2$ animals exceeded that of V1 animals at 14 DIM, and was greater than the $\operatorname{IgG}_{1}: \operatorname{IgG}_{2}$ ratio in both $\mathrm{V} 1$ and $\mathrm{CTL}$ animals at $6 \mathrm{~d}$ PIC $(P<0.01$; Figure $6 \mathrm{C})$. At $21 \mathrm{~d}$ prepartum, multiparous cows had greater serum $\operatorname{IgG}_{1}: \operatorname{IgG}_{2}$ than primiparous heifers $(P<0.01)$, but the opposite was seen at 14 DIM ( $P=0.01$; data not shown).

We did not detect any effects of treatment on serum IgM or IgA concentrations (Table 2). Multiparous cows had higher serum IgM and serum IgA levels than primiparous heifers at $\mathrm{d} 6,30$, and 60 PIC $(P<0.01$; Figure $7 \mathrm{C}$ and $7 \mathrm{D})$. Jersey animals had greater serum IgM concentrations than Holstein animals at 14 DIM (before the third vaccination), and at d 1, 2, 30, and 60 PIC $(P<0.05$; data not shown). Jersey cows had more 

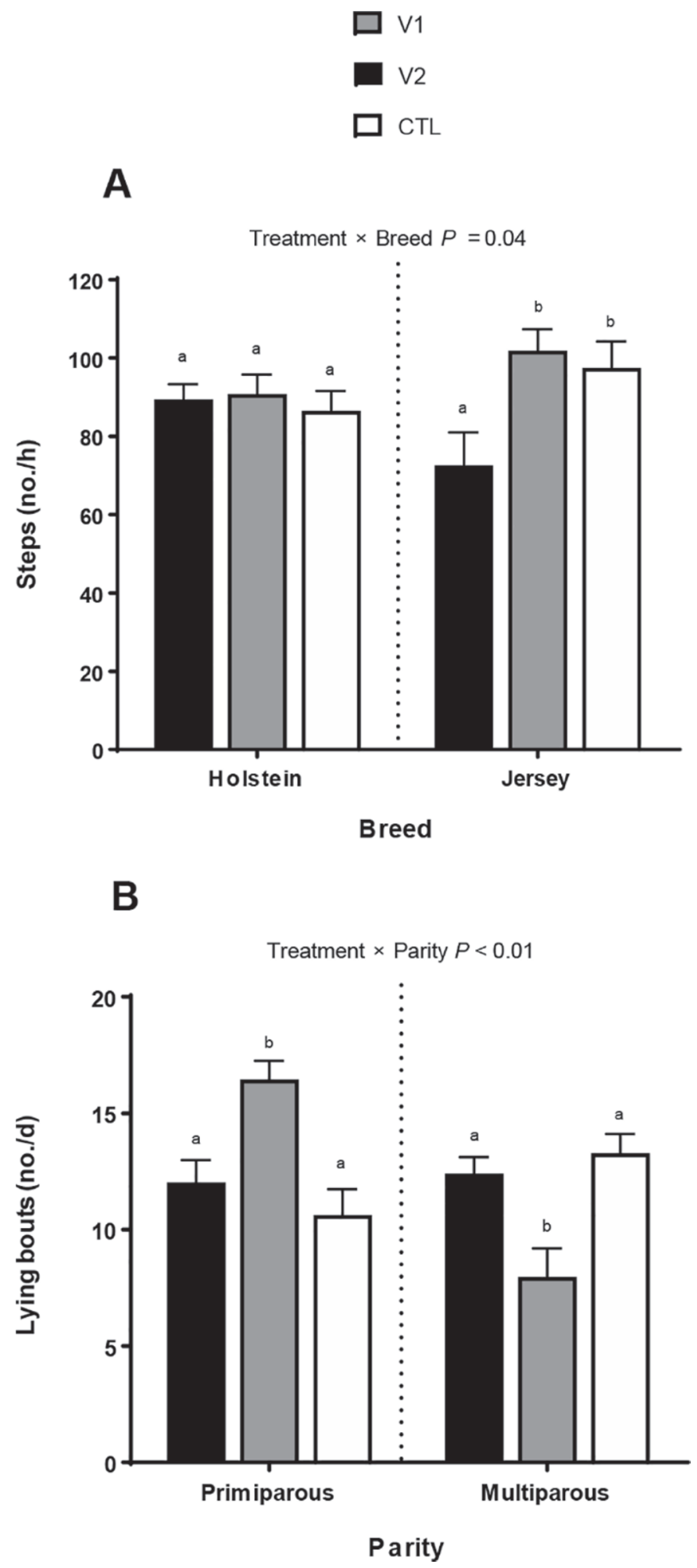

Figure 5. Least squares means ( \pm SEM) of (A) step activity (steps/h) for Holstein and Jersey cows and (B) lying bouts (no./d) for primiparous and multiparous cows vaccinated with vaccine 1 (V1) or vaccine 2 (V2), or unvaccinated controls (CTL) in the $7 \mathrm{~d}$ following an intramammary challenge with Escherichia coli. Different letters (a, b) denote a significant difference $(P<0.05)$ between treatments within breed or parity. serum IgA than their Holstein counterparts at 14 DIM, and at 30 and $60 \mathrm{~d}$ PIC $(P<0.01)$, but at $6 \mathrm{~d}$ PIC, the reverse was true: serum IgA levels in Holsteins exceeded that of Jersey cows $(P<0.05$; data not shown).

Milk IgA concentrations were similar between treatments from d 0 to 6 relative to the challenge, but V1 animals had greater milk IgA levels at d 30 and 60 PIC compared with V2 and CTL animals $(P<0.05$; Figure $6 \mathrm{D})$. Multiparous cows had greater milk IgA levels than primiparous heifers before the challenge $(\mathrm{d} 0)$ and at $\mathrm{d}$ $3,6,30$, and 60 PIC $(P<0.05$; Figure 8$)$. Jersey cows had greater milk IgA levels than Holsteins at d 0 and d 60 PIC $(P<0.05$; data not shown). The levels of $\mathrm{TNF} \alpha$ in milk increased by almost 30 -fold from $\mathrm{d} 0$ to $\mathrm{d} 1$, and declined steadily over time to 7 -fold greater than pre-challenge levels by $6 \mathrm{~d}$ PIC $(P<0.01$; data not shown). We observed no differences in milk TNFo levels between treatment groups, but milk TNFo levels were greater in multiparous cows than in primiparous heifers (Table 2).

\section{DISCUSSION}

We hypothesized that vaccinated dairy cows would have reduced severity of clinical mastitis compared with unvaccinated controls following an intramammary challenge with $E$. coli in peak lactation. All cows in our study developed clinical mastitis in the challenged quarter and showed signs of systemic illness by $15 \mathrm{~h}$ PIC; therefore, a moderate to severe infection was established. The concentration of $E$. coli recovered from the milk of challenged quarters peaked at $12 \mathrm{~h}$ PIC, SCS peaked shortly thereafter at $18 \mathrm{~h}$ PIC, and milk production was halved at $2 \mathrm{~d}$ PIC, following a similar response to a previously described E. coli intramammary challenge (Tomita et al., 2000).

However, contrary to our hypothesis, we observed little difference between vaccinated and CTL cows in clinical response to E. coli. Vaccinated animals developed fever $3 \mathrm{~h}$ earlier than CTL animals, but we found no differences between treatments in quarter bacterial count, milk appearance or SCS, or in milk yield and components measured at the cow level, other than protein yield. Earlier fever would typically indicate a quicker induction of the inflammatory response and systemic involvement that may be associated with faster pathogen recognition or bacterial growth (Mehrzad et al., 2008). However, whether a rapid inflammatory response corresponds to quicker recovery of clinical signs of infection depends on many cow factors (reviewed by Burvenich et al., 2003).

Considerable research into induced or naturally occurring clinical mastitis has focused on the early lactation period, but few have investigated the longer-term 
A

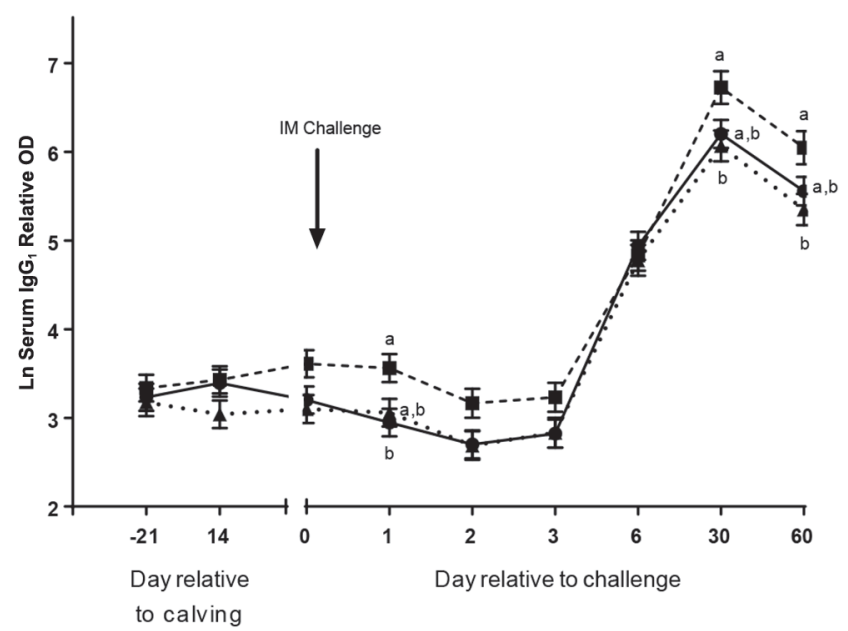

C

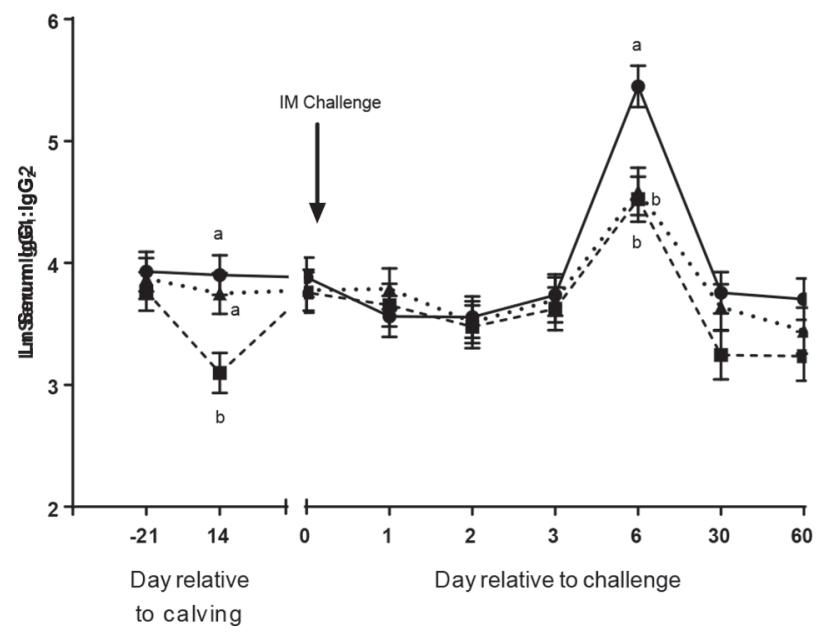

B

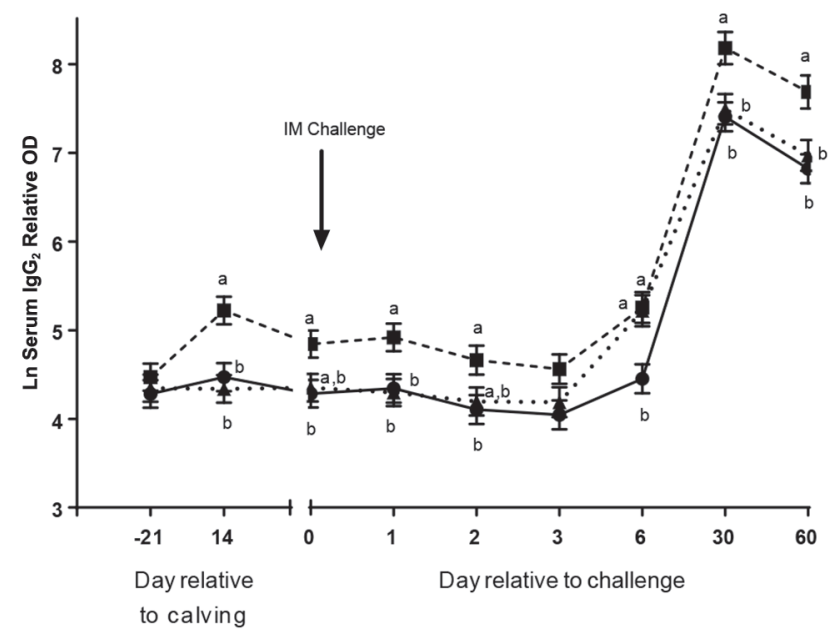

D

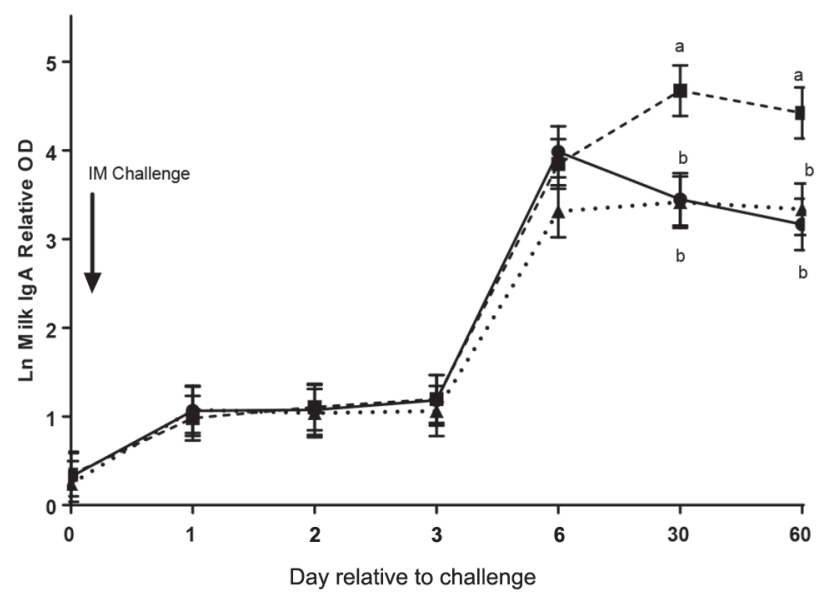

Figure 6. Least squares means $( \pm \mathrm{SEM})$ of the natural logarithmic $(\mathrm{ln})$-transformed relative optical density $(\mathrm{OD})$ of $(\mathrm{A})$ serum $\mathrm{IgG} \mathrm{G}_{1},(\mathrm{~B})$ serum $\mathrm{IgG}_{2}$, (C) serum $\mathrm{IgG}_{1}: \mathrm{IgG}_{2}$ ratio, and (D) milk IgA for cows vaccinated with vaccine 1 (V1) or vaccine 2 (V2), or unvaccinated controls (CTL) following the second and third vaccination given at $\mathrm{d}-21$ and 14 relative to calving, respectively, and immediately before (d 0) and following (d 1, 2, 3, 6, 30, and 60) an intramammary (IM) challenge with Escherichia coli. Values are expressed with a mean shift of 5. Different letters $(\mathrm{a}, \mathrm{b})$ denote a significant difference $(P<0.05)$ between treatments within day.

effects of J5 vaccination using a challenge model. Following experimental mastitis, a protective effect of J5 vaccination in the first 30 DIM was demonstrated for some (Hogan et al., 1995, 2005; Tomita et al., 1998) but not all studies (Smith et al., 1999; Tomita et al., 2000). Compared with cows that did not receive a J5 bacterin, vaccinated cows had reduced peak bacterial counts and SCC (Hogan et al., 2005), a faster decline in E. coli concentration in milk (Hogan et al., 1995; Tomita et al., 1998), a shorter duration of clinical mastitis
(Hogan et al., 2005) or IMI (80 vs. 130 h; Hogan et al., 1995), and a quicker milk yield recovery (Tomita et al., 1998) following induced mastitis. In naturally occurring clinical mastitis studies, vaccination reduced the incidence of coliform clinical mastitis in the first $90 \mathrm{~d}$ of lactation (González et al., 1989; Cullor, 1991; Hogan et al., 1992b) and contributed to a lesser milk yield decline and risk of culling (Wilson et al., 2008, 2009) compared with unvaccinated controls who developed clinical mastitis due to coliform bacteria. Our challenge 


\section{A}

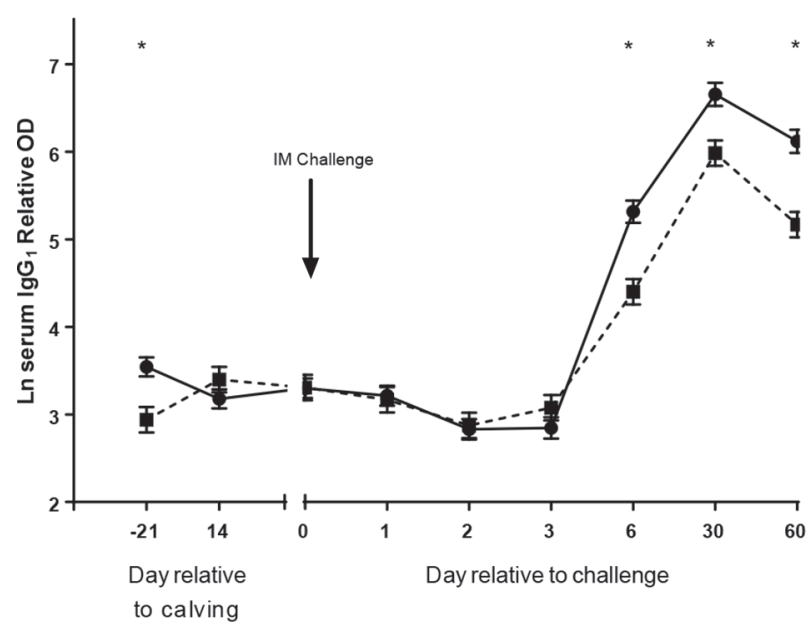

C

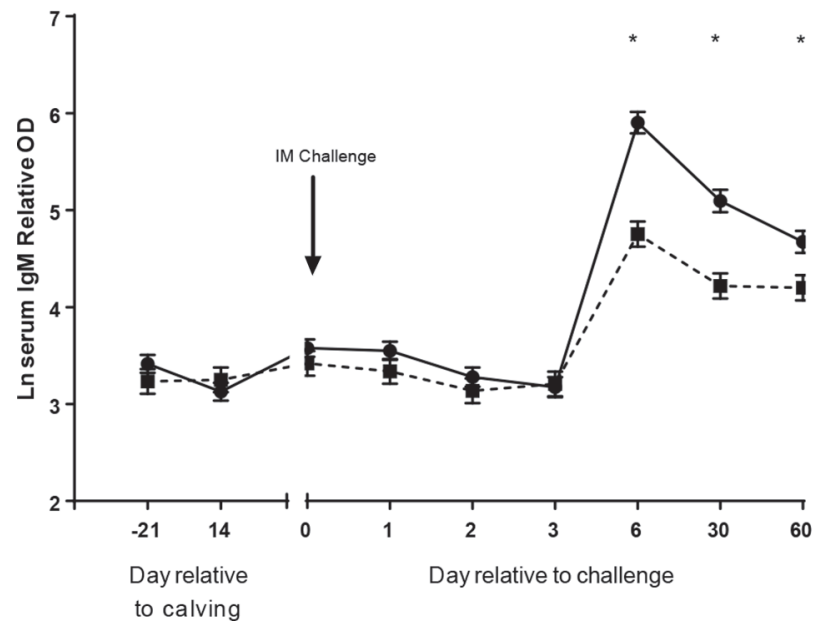

B

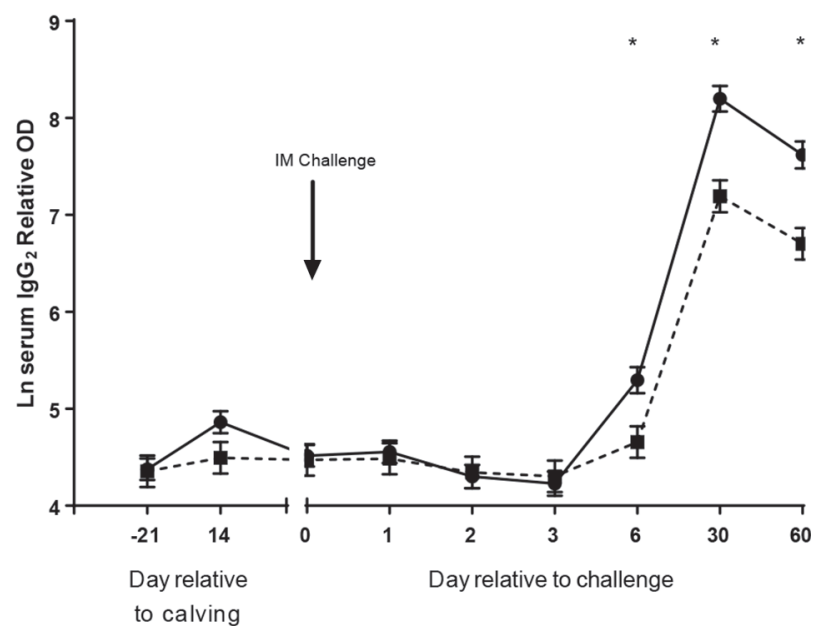

D

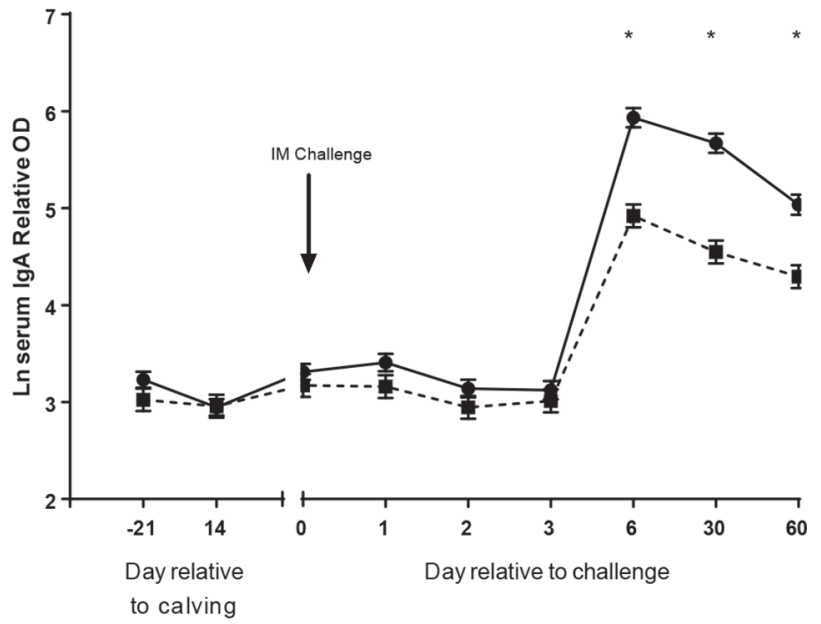

Figure 7. Least squares means $( \pm \mathrm{SEM})$ of the natural logarithmic $(\ln )$-transformed relative optical density $(\mathrm{OD})$ of $(\mathrm{A})$ serum $\mathrm{IgG} \mathrm{G}_{1}$, $(\mathrm{B})$ serum $\mathrm{IgG}_{2}$, (C) serum IgM, and (D) serum IgA for primiparous and multiparous cows following the second and third vaccination given at $\mathrm{d}$ -21 and 14 relative to calving, respectively, and immediately before (d 0$)$ and following (d 1, 2, 3, 6, 30, and 60) intramammary (IM) challenge with Escherichia coli. Values are expressed with a mean shift of 5 . ${ }^{*}$ Significant difference $(P<0.05)$ between parities within time.

study differed in the timing of induced mastitis, which occurred an average of $84 \mathrm{~d}$ after the last vaccine was administered to vaccinated cows at 14 DIM. Waning protection of the $\mathrm{J} 5$ vaccination was evident in the study by Wilson et al. (2009) where the lesser milk yield decline observed following clinical mastitis in vaccinates was no longer apparent after 75 DIM. Moreover, hyperimmunization (6 doses) reduced the incidence of severe clinical mastitis cases between 42 and 126 DIM, compared with cows that received 3 doses (Erskine et al., 2007), and greater $\operatorname{IgG}_{1}$ and $\operatorname{IgG}_{2}$ titers were estab- lished in hyperimmunized cows in a later study (Erskine et al., 2010). The lack of clinical differences between controls and vaccinates in our study suggest that the effects of vaccination were diminished by the time cows received the intramammary challenge at approximately 100 DIM. Although 2 to 3 doses are routine in industry, additional doses may help to protect against coliform mastitis later in lactation.

Although we observed no significant differences in mortality $(P=0.10)$ and morbidity $(P=0.08)$ rates between treatment groups, a numerical difference was 


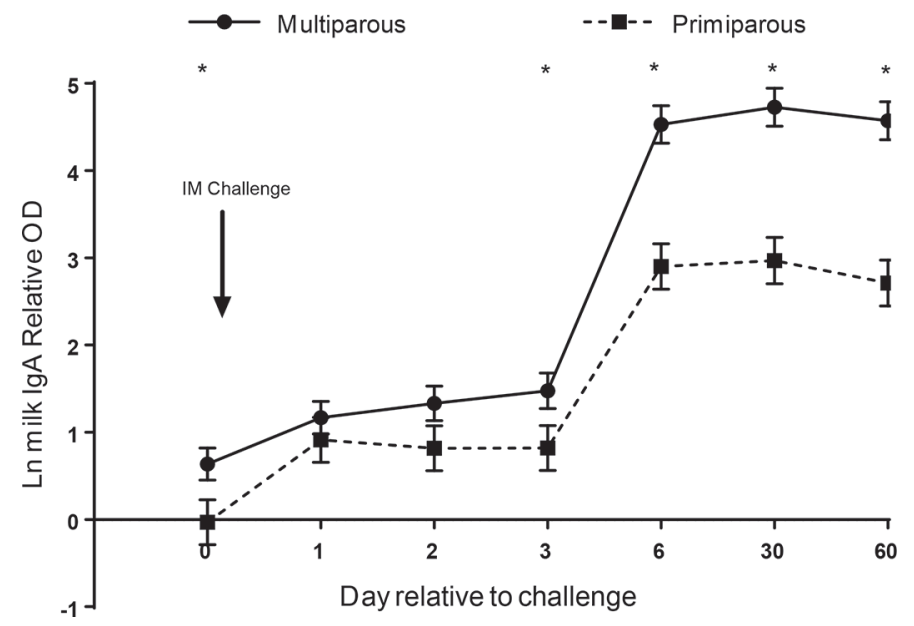

Figure 8 . Least squares means $( \pm$ SEM) of the natural logarithmic (ln)-transformed relative optical density (OD) of milk IgA for primiparous and multiparous cows immediately before (d 0) and following (d 1, 2, 3, 6, 30, and 60) intramammary (IM) challenge with Escherichia coli. Values are expressed with a mean shift of 5 . *Significant difference $(P<0.05)$ between parities within time.

apparent. More cows had to be removed from the study for treatment from the V2 and CTL groups $(\mathrm{n}=3$ each), compared with the V1 group $(\mathrm{n}=1)$, and the 2 cows that were euthanized were both in the CTL group. Due to sample size limitations, we must interpret this finding cautiously. Our study was powered to detect effect sizes reported from early lactation studies, but the differences we demonstrated between vaccinates and controls were much smaller than anticipated. The numbers of animals contributing to morbidity and mortality rates were small, so it is unknown whether this result was of biological significance.

Regarding the behavioral response to the E. coli intramammary challenge, vaccinated animals displayed less restlessness by spending more time lying per bout than CTL animals at $2 \mathrm{~d}$ PIC, but no treatment differences were apparent in total lying time. A large study established that healthy cows housed in free stalls spent $11 \pm 2.1 \mathrm{~h}$ lying/d $(660 \mathrm{~min} / \mathrm{d})$, broken up into $9 \pm 3$ bouts/d of $88 \pm 30 \mathrm{~min} /$ bout (Ito et al., 2009). Variation exists between farms and between individual cows (Ito et al., 2009), but cows in our study spent less time lying overall (mean $554 \mathrm{~min} / \mathrm{d}$ ) and per lying bout 1 d PIC. A recent study demonstrated more deviations in behavior in the "preclinical" phase (0 to $8 \mathrm{~h}$ ) and the "acute" phase (12 to $24 \mathrm{~h}$ ) following challenge with E. coli P4 (O32:H37), compared with the "remission" phase, 32 to $80 \mathrm{~h}$ PIC (de Boyer des Roches et al., 2017). Cows switched between lying and standing positions less often and were found to stand still for longer periods (de Boyer des Roches et al., 2017). Initially, we summarized behavioral data in $3 \mathrm{~h}$ periods for the first $24 \mathrm{~h}$ to assess the immediate response after the challenge. However, because we observed no differences, we summarized the data into $24 \mathrm{~h}$ periods following the time of the challenge. The reduced restlessness at $2 \mathrm{~d}$ PIC for vaccinated cows may indicate less discomfort compared with CTL cows. Although natural sickness behavior is thought to involve more time spent lying to conserve energy and maintain the febrile response (Johnson, 2002), studies involving mastitic cows have demonstrated reduced lying time, particularly in the early stages of an acute infection, such as that caused by infusion of live E. coli (Yeiser et al., 2012) or LPS (Siivonen et al., 2011). The local effects of mastitis, including udder swelling and increased intramammary pressure, might discourage cows from lying, or lead to more frequent position changes in CTL cows. Nevertheless, we found no differences in most of the clinical outcomes evaluated, so the reduced restlessness in vaccinated cows was not associated with quicker recovery.

Although we observed a similar clinical response to intramammary challenge between the 2 vaccinated groups, we found a disparity between vaccinated cows in antibody response. Cows treated with V1 had more serum $\operatorname{IgG}_{2}$ than V2 cows at the third vaccination (14 $\mathrm{d}$ post-calving) and immediately before the challenge through to 60 d PIC. Additionally, V1 cows had greater serum $\operatorname{IgG}_{1}$ at 1,30 , and $60 \mathrm{~d}$ PIC. Because cows were challenged near peak lactation, we did not expect this difference between vaccinated groups. Antibody levels are known to decline over time, hence the need for successive vaccinations with the start of each lactation (Wilson et al., 2009). The difference in antibody levels observed between vaccines in our study may have been related to variations in the composition of the vaccine, such as the adjuvant. The role of the adjuvant is to produce a superior immune response to immunization than the antigen would produce on its own (Awate et al., 2013), but the adjuvant incorporated into each vaccine was not disclosed by the manufacturers. Regardless, the increased antibody response of V1 cows in our study was not associated with reduced severity or quicker recovery of induced clinical mastitis.

Since the introduction of J5 vaccination in the late 1980 s, the mechanism of action has not been clearly established (Dosogne et al., 2002; Schukken et al., 2011). The classical hypothesis was that increased antibody titers to E. coli J5 in vaccinated cows enhanced opsonization of LPS, thereby neutralizing antigen and flagging it for clearance by phagocytes (Tyler et al., 1991; Hogan et al., 1992b). Class switching of $\operatorname{IgM}$ to $\operatorname{IgG}_{1}$ or $\mathrm{IgG}_{2}$ has been reported in $\mathrm{J} 5$ vaccinated cows, where serum IgM levels were greater in unvaccinated controls (Wilson et al., 2009), but we found no difference in serum IgM between treatments in our study. In experi- 
mental mastitis studies, vaccination with a J5 bacterin often led to increased IgG titers above unvaccinated controls, but an improvement in clinical outcomes such as reduced bacterial count and duration of clinical signs has not been consistently reported (Smith et al., 1999; Tomita et al., 2000). A growing body of evidence points to neutrophil recruitment and function having a critical role in defense against $E$. coli, in synergy with adaptive immunity (Hill, 1981; Van Werven et al., 1997; Herry et al., 2017).

We observed a lower ratio of $\operatorname{IgG}_{1}$ to $\operatorname{IgG}_{2}$ for the $\mathrm{V} 1$ group, compared with V2 animals, at 14 DIM and $6 \mathrm{~d}$ PIC. An immune response with greater $\operatorname{IgG}_{2}$ production follows a T-helper type 1 response (Stevens et al., 1988). The T-helper type 1 cells promote inflammation through cytokine production, which initiate class switching from $\operatorname{IgM}$ to $\operatorname{IgG}_{2}$. An important function of $\mathrm{IgG}_{2}$ is as an opsonin that facilitates phagocytosis by neutrophils (Stevens et al., 1988; Estes and Brown, 2002). An influx of neutrophils to the mammary gland occurs on recognition of LPS, and the speed of neutrophil mobilization was found to be important in host defense against E. coli (Hill et al., 1983; Burvenich et al., 2003). Neutrophil trafficking and activation is mediated by $\mathrm{T}$ cells, emphasizing the link between innate and cell-mediated immunity (Shafer-Weaver et al., 1999). The immune response in early lactation favors a T-helper type 2 response, with greater production of $\mathrm{IgG}_{1}$, whereas later in lactation the response shifts to T-helper type 1, which is more protective against mastitis (Shafer-Weaver et al., 1999). Vaccination with a J5 bacterin is hypothesized to reverse that trend to a proinflammatory state in early lactation (Schukken et al., 2011). Accordingly, the lack of clinical differences between vaccinated groups and the unvaccinated CTL animals in the present study may not be surprising, considering that cows were challenged at a time when they are biologically more resistant to mastitis, and that any advantage offered by the J5 bacterin would be diminished because the last vaccination was approximately 12 wk prior.

To further support the relative importance of cellmediated immunity, we report a parity effect, where reduced antibody levels were associated with faster clinical recovery in primiparous heifers. Regardless of vaccination status, primiparous animals had reduced bacterial counts, had lower SCS from $2 \mathrm{~d}$ PIC, returned to normal milk appearance $2 \mathrm{~d}$ earlier, and had a smaller decline in milk production and components than multiparous cows, combined with a weaker antibody response. When administered the same concentration of E. coli via intramammary challenge, primiparous cows were able to clear the infection faster than multiparous cows. A higher SCS was observed in primiparous animals 24 h PIC, which declined more rapidly than for multiparous cows by 3 d PIC. Comparably, another E. coli 727 challenge study demonstrated faster bacterial growth and greater losses in milk production in multiparous cows compared with primiparous heifers (Yeiser et al., 2012). Others have also noted differences in the severity of induced E. coli clinical mastitis between primiparous and multiparous animals (Van Werven et al., 1997; Mehrzad et al., 2002). We observed reduced serum $\operatorname{IgG}_{1}$ levels in primiparous heifers at the second vaccination $(-21 \mathrm{~d}$ relative to calving), and all serum antibodies measured were reduced in primiparous animals at $d$ 6, 30, and 60 PIC compared with multiparous cows. It is reasonable to speculate that antibody production to $E$. coli J5 was weaker in primiparous cows, because younger animals have reduced exposure to coliform mastitis pathogens than multiparous cows, due to a shorter period of lactation (Wilson et al., 1997). Moreover, a lesser antibody response in primiparous heifers, combined with quicker recovery of clinical mastitis, could point to a greater relative importance of cellmediated immunity. A stronger immune response to $E$. coli in the mammary gland of primiparous animals has been partly attributed to enhanced neutrophil function and ability to clear the pathogen (Vangroenweghe et al., 2004). Furthermore, the bactericidal capacity of migrated neutrophils has been demonstrated to differ between primiparous and multiparous animals, with greater viability and oxidative burst activity reported in neutrophils from primiparous animals (Mehrzad et al., 2002). Still, this finding must be interpreted with caution, because studies of immune function typically occur in early lactation, coinciding with the period of immunosuppression commonly reported in transition dairy cows (Shafer-Weaver et al., 1999).

We observed greater concentrations of TNFa in milk of multiparous compared with primiparous animals. In mice, neutrophil recruitment was achieved by $\mathrm{TNF} \alpha$ signaling from macrophages following recognition of E. coli through LPS and the pathogen recognition receptor toll-like receptor-4 (Elazar et al., 2010). We measured $\mathrm{TNF} \alpha$ at $\mathrm{d} 0,1,2,3$, and 6 PIC, but more frequent sampling in the first $24 \mathrm{~h}$ following challenge may have revealed whether a quicker increase in $\mathrm{TNF} \alpha$ in primiparous animals coincided with the greater SCS observed $24 \mathrm{~h}$ PIC. Nonetheless, in multiparous cows, the greater TNF $\alpha$ at the time points we measured were likely associated with the increased $E$. coli concentration at $15 \mathrm{~h}$ PIC and increased SCS at 3 d PIC. Günther et al. (2010) demonstrated an association between the concentration of $E$. coli in bovine milk and the level of cytokines such as TNFo and IL- 8 induced as part of the immune response. We speculate that a delay in neutrophil recruitment and potentially reduced neutro- 
phil function may offer explanations for the increased duration of clinical signs, greater bacterial counts, and longer SCS elevation seen in multiparous cows in our study, even though antibody levels were greater. Further research into neutrophil recruitment and function, and synergy with the adaptive immune system, is necessary to augment our understanding of the protection against coliform mastitis provided by vaccination with a J5 bacterin.

\section{CONCLUSIONS}

Overall, the clinical responses to E. coli intramammary challenge in peak lactation were not vastly different between vaccinated animals and unvaccinated controls. Vaccinated animals displayed fever $3 \mathrm{~h}$ earlier and less restlessness 2 d PIC compared with control animals, but we found no differences between treatments for quarter bacterial counts, milk appearance, SCS, and milk yield and components at the cow level. Although V1 cows had greater $\operatorname{IgG}_{1}$ and $\mathrm{IgG}_{2}$ production than V2 and CTL cows, this was not accompanied by any improvement in clinical recovery from the $E$. coli challenge. Additionally, primiparous heifers produced consistently fewer antibodies than multiparous cows, but displayed less severe signs of clinical mastitis during the post-challenge period. Immunization with either J5 bacterin did not reduce clinical signs of mastitis in cows challenged at 100 DIM, demonstrating that the effects of J5 vaccination had diminished by peak lactation. Additional doses may be necessary to provide longer-lasting protection against coliform mastitis later in lactation.

\section{ACKNOWLEDGMENTS}

We thank all the farm staff at Virginia Tech Dairy Center for assistance with animal handling, and A. Willard, C. Henderson, and K. McCauley for assistance with sample collection and laboratory analyses. I. Kanevsky (Pfizer Inc., New York City, NY) and A. J. Duncan (Virginia Tech, Blacksburg, VA) are acknowledged for their help with laboratory training and results interpretation. Nicole Steele is partially supported by New Zealand dairy farmers through DairyNZ Inc.

\section{REFERENCES}

Ali, A. K. A., and G. E. Shook. 1980. An optimum transformation for somatic cell concentration in milk. J. Dairy Sci. 63:487-490.

Awate, S., L. A. B. Babiuk, and G. Mutwiri. 2013. Mechanisms of action of adjuvants. Front. Immunol. 4:114-123.

Burvenich, C., V. Van Merris, J. Mehrzad, A. Diez-Fraile, and L. Duchateau. 2003. Severity of Escherichia coli mastitis is mainly determined by cow factors. Vet. Res. 34:521-564.
Chaiyotwittayakun, A., J. L. Burton, P. S. D. Weber, K. Kizilkaya, F. F. Cardoso, and R. J. Erskine. 2004. Hyperimmunization of steers with J5 Escherichia coli bacterin: effects on isotype-specific serum antibody responses and cross reactivity with heterogeneous gramnegative bacteria. J. Dairy Sci. 87:3375-3385.

Cullor, J. S. 1991. The Escherichia coli J5 vaccine: Investigating a new tool to combat mastitis. Vet. Med. 86:836-844.

de Boyer des Roches, A., M. Faure, A. Lussert, V. Herry, P. Rainard, D. Durand, and G. Foucras. 2017. Behavioral and patho-physiological response as possible signs of pain in dairy cows during Escherichia coli mastitis: A pilot study. J. Dairy Sci. 100:8385-8397.

Dosogne, H., F. Vangroenweghe, and C. Burvenich. 2002. Potential mechanism of action of $\mathrm{J} 5$ vaccine in protection against severe bovine coliform mastitis. Vet. Res. 33:1-12.

Elazar, S., E. Gonen, A. Livneh-Kol, I. Rosenshine, and N. Y. Shpigel. 2010. Essential role of neutrophils but not mammary alveolar macrophages in a murine model of acute Escherichia coli mastitis. Vet. Res. 41:53-65.

Erskine, R. J., A. R. Brockett, N. D. Beeching, R. W. Hull, and P. C. Bartlett. 2010. Effect of changes in number of doses and anatomic location for administration of an Escherichia coli bacterin on serum IgG1 and IgG2 concentrations in dairy cows. Am. J. Vet. Res. 71:120-124.

Erskine, R. J., E. J. Van Dyk, P. C. Bartlett, J. L. Burton, and M. C. Boyle. 2007. Effect of hyperimmunization with an Escherichia coli J5 bacterin in adult lactating dairy cows. J. Am. Vet. Med. Assoc. 231:1092-1097.

Estes, D. M., and W. C. Brown. 2002. Type 1 and type 2 responses in regulation of Ig isotype expression in cattle. Vet. Immunol. Immunopathol. 90:1-10.

González, R. N., J. S. Cullor, D. E. Jasper, T. B. Farver, R. B. Bushnell, and M. N. Oliver. 1989. Prevention of clinical coliform mastitis in dairy cows by a mutant Escherichia coli vaccine. Can. J. Vet. Res. 53:301-305.

Günther, J., S. Liu, K. Esch, H. J. Schuberth, and H. M. Seyfert 2010. Stimulated expression of TNF- $\alpha$ and IL-8, but not of lingual antimicrobial peptide reflects the concentration of pathogens contacting bovine mammary epithelial cells. Vet. Immunol. Immunopathol. 135:152-157.

Herry, V., C. Gitton, G. Tabouret, M. Répérant, L. Forge, C. Tasca, F. B. Gilbert, E. Guitton, C. Barc, C. Staub, D. G. Smith, P. Germon, G. Foucras, and P. Rainard. 2017. Local immunization impacts the response of dairy cows to Escherichia coli mastitis. Sci. Rep. 7:3441-3458.

Hill, A. W. 1981. Factors influencing the outcome of Escherichia coli mastitis in the dairy cow. Res. Vet. Sci. 31:107-112.

Hill, A. W., D. J. S. Heneghan, and M. R. Williams. 1983. The opsonic activity of bovine milk whey for the phagocytosis and killing by neutrophils of encapsulated and non-encapsulated Escherichia coli. Vet. Microbiol. 8:293-300.

Hogan, J., and K. L. Smith. 2003. Coliform mastitis. Vet. Res. 34:507519.

Hogan, J. S., V. B. Cannon, K. L. Smith, C. Rinehart, and S. Miller. 2005. Effects of adjuvants on safety and efficacy of an Escherichia coli J5 bacterin. J. Dairy Sci. 88:534-542.

Hogan, J. S., K. L. Smith, D. A. Todhunter, and P. S. Schoenberger. 1992b. Field trial to determine efficacy of an Escherichia coli J5 mastitis vaccine. J. Dairy Sci. 75:78-84.

Hogan, J. S., W. P. Weiss, K. L. Smith, D. A. Todhunter, P. S. Schoenberger, and L. M. Sordillo. 1995. Effects of an Escherichia coli J5 vaccine on mild clinical coliform mastitis. J. Dairy Sci. 78:285-290.

Hogan, J. S., W. P. Weiss, D. A. Todhunter, K. L. Smith, and P. S. Schoenberger. 1992a. Efficacy of an Escherichia coli J5 mastitis vaccine in an experimental challenge trial. J. Dairy Sci. 75:415422.

Ito, K., D. M. Weary, and M. A. G. Von Keyserlingk. 2009. Lying behavior: Assessing within-and between-herd variation in free-stallhoused dairy cows. J. Dairy Sci. 92:4412-4420.

Johnson, R. W. 2002. The concept of sickness behavior: A brief chronological account of four key discoveries. Vet. Immunol. Immunopathol. 87:443-450. 
Kaniyamattam, K., and A. De Vries. 2014. Agreement between milk fat, protein, and lactose observations collected from the Dairy Herd Improvement Association (DHIA) and a real-time milk analyzer. J. Dairy Sci. 97:2896-2908.

Mehrzad, J., L. Duchateau, S. Pyörälä, and C. Burvenich. 2002. Blood and milk neutrophil chemiluminescence and viability in primiparous and pluriparous dairy cows during late pregnancy, around parturition and early lactation. J. Dairy Sci. 85:3268-3276.

Mehrzad, J., D. Janssen, L. Duchateau, and C. Burvenich. 2008. Increase in Escherichia coli inoculum dose accelerates CD8+ T-cell trafficking in the primiparous bovine mammary gland. J. Dairy Sci. 91:193-201.

Middleton, J., L. Fox, G. Pighetti, and C. Petersson-Wolfe. 2017. Laboratory handbook on bovine mastitis. National Mastitis Council, New Prague, MN.

Rollin, E., K. C. Dhuyvetter, and M. W. Overton. 2015. The cost of clinical mastitis in the first 30 days of lactation: An economic modeling tool. Prev. Vet. Med. 122:257-264.

Schukken, Y. H., J. Günther, J. Fitzpatrick, M. Fontaine, L. Goetze, O. Holst, J. Leigh, W. Petzl, H.-J. Schuberth, and A. Sipka. 2011. Host-response patterns of intramammary infections in dairy cows. Vet. Immunol. Immunopathol. 144:270-289.

Shafer-Weaver, K. A., C. M. Corl, and L. M. Sordillo. 1999. Shifts in bovine CD4+ subpopulations increase T-helper-2 compared with T-helper-1 effector cells during the postpartum period. J. Dairy Sci. 82:1696-1706.

Siivonen, J., S. Taponen, M. Hovinen, M. Pastell, B. J. Lensink, S. Pyorala, and L. Hanninen. 2011. Impact of acute clinical mastitis on cow behavior. Appl. Anim. Behav. Sci. 132:101-106.

Smith, J. L., J. S. Hogan, and K. L. Smith. 1999. Efficacy of intramammary immunization with an Escherichia coli J5 bacterin. J. Dairy Sci. 82:2582-2588.

Stevens, T. L., A. Bossie, V. M. Sanders, R. Fernandez-Botran, R. L. Coffman, T. R. Mosmann, and E. S. Vitetta. 1988. Regulation of antibody isotype secretion by subsets of antigen-specific helper $\mathrm{T}$ cells. Nature 334:255-258.

Tomita, G. M., S. C. Nickerson, W. E. Owens, and B. Wren. 1998. Influence of route of vaccine administration against experimental intramammary infection caused by Escherichia coli. J. Dairy Sci. 81:2159-2164.

Tomita, G. M., C. H. Ray, S. C. Nickerson, W. E. Owens, and G. F. Gallo. 2000. A comparison of two commercially available Escherichia coli J5 vaccines against $E$. coli intramammary challenge. J. Dairy Sci. 83:2276-2281.
Tyler, J., H. Spears, J. Cullor, W. Smith, R. Nelson, and J. Martin. 1991. Antigenic homology among Gram-negative organisms isolated from cattle with clinical mastitis. J. Dairy Sci. 74:1235-1242.

USDA. 2016. Dairy 2014, Dairy Cattle Management Practices in the United States, 2014. USDA-APHIS-VS-CEAH-NAHMS, Fort Collins, CO.

Van Werven, T., E. N. Noordhuizen-Stassen, A. J. J. M. Daemen, Y. H. Schukken, A. Brand, and C. Burvenich. 1997. Preinfection in vitro chemotaxis, phagocytosis, oxidative burst, and expression of CD11/CD18 receptors and their predictive capacity on the outcome of mastitis induced in dairy cows with Escherichia coli. J. Dairy Sci. 80:67-74.

Vangroenweghe, F., P. Rainard, M. Paape, L. Duchateau, and C. Burvenich. 2004. Increase of Escherichia coli inoculum doses induces faster innate immune response in primiparous cows. J. Dairy Sci. $87: 4132-4144$

Wilson, D. J., R. N. Gonzalez, and H. H. Das. 1997. Bovine mastitis pathogens in New York and Pennsylvania: Prevalence and effects on somatic cell count and milk production. J. Dairy Sci. 80:2592-2598.

Wilson, D. J., Y. T. Grohn, G. J. Bennett, R. N. González, Y. H. Schukken, and J. Spatz. 2008. Milk production change following clinical mastitis and reproductive performance compared among J5 vaccinated and control dairy cattle. J. Dairy Sci. 91:3869-3879.

Wilson, D. J., B. A. Mallard, J. L. Burton, Y. H. Schukken, and Y. T. Grohn. 2009. Association of Escherichia coli J5-specific serum antibody responses with clinical mastitis outcome for $\mathrm{J} 5$ vaccinate and control dairy cattle. Clin. Vaccine Immunol. 16:209-217.

Yeiser, E. E., K. E. Leslie, M. L. McGilliard, and C. S. Petersson-Wolfe. 2012. The effects of experimentally induced Escherichia coli mastitis and flunixin meglumine administration on activity measures, feed intake, and milk parameters. J. Dairy Sci. 95:4939-4949.

\section{ORCIDS}

N. M. Steele $\odot$ https://orcid.org/0000-0001-9915-0954

T. H. Swartz @ https://orcid.org/0000-0002-9457-2418

R. R. Cockrum @ https://orcid.org/0000-0002-0040-238X

S. J. Lacy-Hulbert @ https://orcid.org/0000-0002-9847-1294

J. Hogan $\odot$ https://orcid.org/0000-0001-8211-9029

C. S. Petersson-Wolfe @ https://orcid.org/0000-0002-2766-1306 